\title{
TAMAN SEMPUR DAN RUANG PUBLIK: Analisis Geo-Semiotik dan Etnografi
}

\author{
Justito Adiprasetio \\ Fakultas Ilmu Komunikasi Universitas Padjadjaran, Jl. Raya Bandung Sumedang \\ KM 21, justitoadiprasetio@gmail.com \\ Sandi Jaya Saputra \\ Fakultas Ilmu Komunikasi Universitas Padjadjaran, Jl. Raya Bandung Sumedang \\ KM 21, sandijayasaputra85@gmail.com
}

\begin{abstract}
Since 2016, Public Park in Indonesia, particularly in West Java has significantly been revitalized. Taman Sempur is one of public parks located in West Java that spent about $R p 2.2$ billion for its revitalization process. That massive amount was poured out in order to develop public space for the community. Taman Sempur is a compound where Taman Kaulinan, Taman Skateboard, Taman Ekspresi, big pedestrian and few sports facilities with its own specific functions stand. This research, that applied the combination of geosemiotic and ethnographic analysis, attempted to observe how meaningful Taman Sempur as urban public space for the community through public space and public sphere approaches. The existing modality indicates that the community have certain attention to participate in Taman Sempur as public space, with some of its flaws in material dimension aspect. At the same time, public sphere nuances still vaguely felt, considering the community's awareness were not full and even due to habitus individual conflict while becoming part of the "public".
\end{abstract}

Keywords: Taman Sempur, Urban Public Space, Public Sphere, Geo-Semiotic

\begin{abstract}
Abstrak
Sejak 2016, taman-taman Kota di Indonesia dan khususnya Jawa Barat mengalami revitalisasi besar-besaran. Taman Sempur adalah taman yang dalam proses revitalisasinya telah menelan anggaran 2,2 miliar. Jumlah yang tak sedikit tersebut digelentorkan dengan tujuan untuk membangun ruang publik bagi warga. Taman Sempur sendiri merupakan komplek taman, di mana di dalamnya terdapat Taman Kaulinan, Taman Skateboard, Taman Ekspresi, pedestrian besar dan beberapa fasilitas olahraga dengan masing-masing memiliki fungsi spesifik. Penelitian ini dengan menggunakan piranti analisis geo-semiotik yang digabungkan dengan analisis etnografi, berupaya menjawab sejauh apa Taman Sempur telah menjadi ruang publik urban bagi warga dengan pendekatan public space maupun public sphere. Modalitas yang ada menunjukkan warga memiliki atensi untuk berpartisipasi di Taman Sempur sebagai public space, dengan beberapa kekurangan di sisi dimensi material. Sedangkan nuansa public sphere masih terasa tipis, mengingat kesadaran warga tidak penuh dan merata karena terbentur habitus individual ketika menjadi bagian dari "publik".
\end{abstract}

Keyword $\quad$ : Taman Sempur, Ruang Publik Urban, Public Sphere, Geo-Semiotik 


\section{Pendahuluan}

Sejak 2016, taman-taman Kota di Indonesia mengalami revitalisasi besarbesaran. Revitalisasi taman juga dilakukan di Kota Bogor. Tiga puluh taman telah masuk dalam program revitalisasi pemerintah Kota Bogor hingga 2018. Program revitalisasi diprogramkan pemerintah dengan tujuan meningkatkan manfaat sarana interaksi sosial bagi warga Kota Bogor dan sekitarnya (Nugroho, Lingga Avian, 2018).

Salah satu taman kota yang menjadi andalan Kota Bogor adalah Taman Sempur. Taman Sempur adalah taman yang paling besar menelan biaya pembangunan. Sejak 2017, proyek revitalisasi Taman Sempur menghabiskan Rp 2,2 miliar. Dalam kurun waktu satu tahun ke depan, akan digelontorkan Rp 2,3 miliar untuk perbaikan jalur jogging di Taman Sempur. Total anggaran yang dialokasikan untuk proyek pembangunan Taman yang terletak di pusat Kota Bogor ini mencapai $\mathrm{Rp}$ 4,5 miliar untuk dua tahun.

Tujuan revitalisasi Taman Sempur selain sebagai penguatan keberadaan ruang publik bagi warga juga sebagai penopang keberadaan Kebun Raya Bogor. Bima Arya, Walikota Bogor 2015-2019, menjelaskan bahwa Lapangan Sempur akan menambah pilihan aktivitas warga dan wisatawan (Farhan, 2017).

Jika taman kota adalah representasi identitas kota, Taman Sempur adalah representasi identitas Kota Bogor (Utama, 2013). Keberadaan pohon berusia puluhan dan ratusan tahun yang rindang dan besar membuat identitas Kota Bogor menjadi kuat dan saling melengkapi dengan nuansa streetscape dan penandapenanda lainnya, yaitu bangunan- bangunan masa kolonial yang ada di sekitar Taman Sempur (Hartanti, 2014). Identitas yang berpotensi memperkuat rasa kepemilikan bersama atas kota dan berbagai elemen yang terdapat di dalamnya (Low \& Altman, 1992).

Taman Sempur sebagai ruang publik urban menawarkan sarana pelarian diri (escape) bagi rutinitas dan kejengahan kelas pekerja di hari-hari setelah rutinitas kota. Seperti diketahui, tak sedikit warga Kota Bogor yang bekerja secara commuting di Jakarta, dan kota-kota lain di sekitar ibu kota. Letaknya yang berhimpitan dengan Kebun Raya Bogor, yang merupakan salah satu objek wisata utama warga Jabodetabek, membuat Taman Sempur hampir tidak mungkin luput dari perhatian. Taman Sempur adalah contoh bagaimana ruang publik urban berusaha dioptimalkan oleh pemerintah Kota Bogor, sebagai penunjang modernisasi di wilayah sentral pembangunan nasional.

Taman Sempur sebelum mengalami revitalisasi (25 Juli 2016 - 2 Februari 2017)- sebelumnya bernama Lapangan Sempur - semata hanya menjadi tempat warga berolahraga: jogging dan bermain basket, daerah jajanan di sekitarpun diatur seadanya. Namun, sejak mengalami proses revitalisasi, Taman Sempur telah menjadi ruang publik urban di mana ia menjadi sarana penopang berbagai aktivitas warga, tidak hanya berolahraga, tapi juga menghabiskan waktu luang mereka untuk bertamasya di sore hari maupun akhir pekan, mengajak anak-anak bermain karena keberadaan fasilitas permainan anak, beraktivitas kolektif bersama warga yang lain. 
Taman Sempur sebagai sasana keberadaan aktivitas warga menjadi katalisator yang menggenjot demokratisasi di Kota Bogor. Demokratisasi dalam konteks politik yang subtil, di mana warga diajak mengenal dan berinteraksi satusama lain di ruang yang dimiliki secara bersama dibayangkan dapat menjamin kesetaraan di antara elemen-elemen di dalamnya. Pada posisi tersebut, kita dapat melihat bagaimana Taman Sepur sedang diupayakan menjadi public sphere - dalam definisi Habermasian.

Terdapat relasi yang beririsan antara keberadaan public space dan public sphere. Bila yang kedua berkaitan dengan bagaimana diskursus demokrasi bekerja dalam suatu ruang tertentu, maka yang pertama adalah tentang ruang yang diberikan dan difungsikan untuk kebutuhan warga.

Ruang dalam definisi apapun Space, Sphere atau Place - tidak pernah benar-benar netral karena ruang selalu merefleksikan sosial dan relasi kuasa, interaksi, proses historis, dan pengalaman subjektif dari penggunanya (Low, 2000; Harvey, 1990). Ruang seperti taman, dapat menjadi tempat di mana kohesi sosial bekerja (L'Aoustet \& Griffet, 2004: 175), praktik penyingkiran dalam kehidupan sosial (Wezkalnys, 2010), dan tempat di mana ideologi-ideologi komunitas yang menjadi bagian dari publik dapat dipetakan (Rotenberg, 2005: 139).

Ruang publik urban adalah tempat yang bermaknai dan dimaknai dalam praktik kehidupan sehari-hari untuk memicu keterlibatan warga sebagai bagian dari publik (Warpole, 1997), kewargaan aktif dari negara maupun kota (Hubbard, 2001; McCann, 2002; Schaller \& Modan, 2005), dan pemberdayaan komunitas (Hou, 2010). Dalam definisi yang lebih teknis (Kohn's, 2008: 481-482), public space adalah ruang yang dapat diakses oleh siapapun, dimiliki oleh pemerintahan dan bekerja secara intersubjektif, di mana setiap orang dapat berinteraksi satu sama lain di sana.

Studi-studi yang berkait dengan bagaimana ruang publik urban bekerja menunjukkan ruang publik urban memiliki implikasi langsung terhadap demokratisasi warga dan relasinya dengan kota. Taman sebagai ruang publik urban menciptakan rasa kedekatan serta kepemilikan warga dengan wilayah tersebut (low \& Altman, 1992). Ruang publik urban juga memiliki potensi untuk mendorong hubungan antar-ras dan etnis (Shinew, Glover, \& Parry, 2004), mendorong keterlibatan masyarakat (McInroy, 2000), mendorong prakarsa regenerasi perkotaan (Glover, 2003), dan membangun kapasitas masyarakat (Pask, 2010). Fungsi-fungsi ini konsisten dengan tujuan tradisional dari rekreasi masyarakat (Glover \& Stewart, 2006) dan berkontribusi terhadap kehidupan komunitas secara keseluruhan (Florida, 2002).

Implikasi-implikasi dari ruang publik urban adalah terbangunnya kultur demokrasi dalam tubuh "publik" atau, dengan kata lain, terbangunnya public sphere. Public sphere dalam definisi Habermas (2008) adalah "the sphere of private individuals come together as a public" - ruang/bidang di mana individu privat datang bersama sebagai publik. Fraser (1990) menjelaskan bahwa karakter public sphere selalu merupakan "teater" untuk interaksi sosial, di mana aktivitas politis teraktualisasi melalui medium untuk beraktivitas dan berbicara. Public sphere dapat terjadi bila partisipannya memiliki modalitas awal, yaitu nalar sebagai basis untuk memikirkan kepentingan bersama, tidak hanya untuk dirinya sendiri (Habermas, 2008: 27), dan walaupun sebagian orang yang lain tidak datang dalam ruang tersebut, partisipan lainnya dengan pengetahuan yang ia miliki akan berargumen dan berlaku mewakili 
mereka, menyadari bahwa terdapat kategori yang lebih besar dan menaungi semua, yaitu "kepentingan publik" (Habermas, 2008: 37).

Pembentukan public sphere, tidak melulu bekerja secara natural dan tak disadari. Public sphere sebagai ruang (sosial) dapat direkayasa terbentuknya oleh masyarakat dengan berbagai kesadaran dan ikhtiar akan pentingnya kebutuhan bersama. Mengikuti konsep Henrik Lefebvre, ruang (sosial) adalah produk (sosial) - (social) space is a (social) product). Ruang (sosial) tidak muncul secara acak dan spontan, tapi merupakan hasil produksi bangunan sosial (yang disusun oleh konstruksi nilai dan makna yang melibatkan kontestasi sosial) (Lefebvre, 1991). Oleh karena itu, dibutuhkan modalitas yang tidak tunggal untuk menyusun aspek-aspek kepublikan.

Walaupun suatu taman dibangun dengan berbagai fasilitas dan sarana, tidak menjamin bahwa taman tersebut akan serta merta berfungsi sebagai ruang sosial dan memiliki public sphere. Ini karena terkait dengan kepemilikan atau aksesibilitas pada ruang. Relasi sosial atas kota tidak akan sehat bila lingkungan yang ada menghambat terjadinya interaksi sosial (Byers 1998). Kepemilikan ruang dan keterbatasan aksesibilitas akan membentuk persepsi individu atas bagaimana publik mengakses suatu ruang. Terdapat beberapa kasus di mana proliferasi kemitraan kontemporer seperti penyediaan layanan publik yang mengaburkan batas antara publik dan swasta (Glover \& Burton, 1998). Pengaburan tersebut bekerja melalui berbagai aspek seperti: sponsor, pembagian modal antara pemerintah dan swasta, outsourcing yang kemudian berimplikasi kepada kolaborasi antara agensi publik dan komersial. Pada akhirnya, nilai dan potensi keberadaan ruang adalah seberapa besar dan seberapa optimal terjadinya interaksi sosial yang melibatkan pertukaran kebudayaan, nilai, dan makna (Lloyd \& Auld, 2003: 347).

Gestur-gestur personal (habitus), interaksi antar individu di dalamnya, infrastruktur, ataupun aktivitas yang seluruhnya terdapat dalam konteks keruangan taman kota adalah representasi konstruksi sosial yang dapat menjadi tolok ukur bagaimana struktur sosial dan struktur ideologi bekerja di suatu kota (Lefebvre, 1991).

Dengan mencoba memahami bagaimana multi-modalitas dalam ruang bekerja, kita dapat melihat bagaimana taman kota dapat menjadi penopang dari proses produksi relasi spasial. Dalam konteks ini, studi ini menjadi mendesak untuk dilakukan. Penelitian ini berusaha membaca bagaimana Taman Sempur berhasil menjadi bagian dari relasi multimodalitas dalam proses produksi ruang sosial sehingga tercipta ruang publik urban dalam telisik public space dan public sphere.

\section{Metode}

Metode penelitian ini adalah gabungan antara geo-semiotik dan etnografi. Geosemiotik adalah metode yang digunakan untuk membaca makna sosial dan relasinya dengan dunia material, sedangkan etnografi digunakan untuk membaca struktur ideologi dan pengalaman subjek-subjek yang mengakses dan menggunakan Taman Kota tersebut.

Tiga sistem utama geo-semiotik adalah: susunan interaksi, semiotika visual dan 'place semiotics' (Scollon \& Scollon, 2013: 8). Susunan interaksi adalah penilaian tentang bagaimana aktivitas tubuh-tubuh manusia dapat menjadi indeks aktivitas sosial yang ada, di mana meliputi tuturan, pergerakan maupun 
gestur) (Scollon \& Scollon, 2013: 13). Elemen susunan interaksi ini dapat dilihat dari: rasa waktu (the sense of time): urgency, monochronism/polychronism (multitasking); ruang perseptual (visualpenglihatan, auditory-pendengaran, olfactory-penciuman, thermal-suhu, haptic-sentuhan); jarak interpersonal: intim, personal, sosial, publik; penampilan 'depan' personal: pakaian dan peralatan yang digunakan, civil inattention (konsep yang dipinjam dari Erving Goffman: bagaimana kita tidak menjadi sekaligus memberikan perhatian dari orang lain di sekitar). Semiotika visual, yaitu tandatanda meliputi teks dan gambar yang nampak secara visual: merepresentasikan partisipan (naratif atau konseptual), modalitas visual (saturasi warna, diferensiasi warna, modulasi warna, kontekstualisasi, representasi, kedalaman, illuminasi, terang cahaya), komposisi (informasi yang tersentralisasi atau terpolarisasi), partisipan interaktif. Sedangkan place-semiotic meliputi pembacaan terhadap semua simbol nonlinguistik lainnya yang secara langsung atau tidak langsung mewakili bahasa. Guna ruang: bagian depan atau publik (pameran / tampilan, bagian, penggunaan khusus, aman), belakang panggung atau pribadi, ruang peraturan (lalu lintas kendaraan, lalu lintas pejalan kaki, pemberitahuan publik), ruang komersial, ruang transgresif (misalnya tempat tinggal tunawisma).

Penerapan geo-semiotik dalam penelitian ini tidak akan menitikberatkan pada tanda-tanda linguistik semata, tapi pada bagaimana berbagai elemen dalam ruang dan bagaimana tubuh subjek menggunakan spasialitas Taman Sempur. Pembagiannya disusun pada 3 level, yakni aktivitas level besar untuk menunjukkan aktivitas skala besar, seperti pertemuan, yang kemudian akan memicu 'rantai aktivitas kecil yang beragam (Norris, 2004: 13). Aktivitas level rendah untuk menunjukkan aktivitas yang lebih kecil dan subtil, seperti gestur, tatapan, prilaku yang akan menjadi rantai interaksi di level rendah yang lain (Norris, 2004: 13). Terakhir adalah aktivitas beku yang menunjukkan artefak material, yang menjadi latar dan memediasi interaksi dalam aspek produksi (sosial) mereka. Dari tiga level tersebut, kita dapat membuat dinstingsi bahwa terdapat dua set dalam mode interaksinya, yaitu 'Embodied' modes, yang terdiri dari gestur, tatapan, dan postur. 'Disembodied' modes, yaitu aspek layout, mode spasial dan media (Jewitt, Bezemer dan O'Halloran: 2016: 115). Elemen kedua mode tersebut, dan relasi di antaranya akan menghasilkan modalitas dan relasi di antara modalitasmodalitas (sistem penandaan yang menunjukkan bagaimana manusia mengorganisasikan makna dari pengalaman dan kategori kebutuhan, kemungkinan, peluang, keinginan, pengetahuan, izin, dan tugas (Picione et all, 2017).

Modalitas dan multimodalitas tersebut kemudian dibaca dengan mulamula menggunakan piranti semiotika Peirce-an (ikon-simbol-indeks) dilanjutkan ke pembacaan yang lebih makro sebagai bagian dari bagaimana wacana public space dan public sphere bekerja di Taman Sempur.

Dalam prosesnya, analisis akan dilengkapi dengan etnografi partisipatif, yang dilakukan untuk melihat dan memahami bagaimana warga merespon Taman Sempur dengan memberikan perhatian terhadap relasi sosial di Taman Sempur. Penggunaan etnografi dalam penelitian ini diharapkan dapat membuat desain riset penelitian ini fleksibel dan menggunakan kategori teoritikal yang cenderung grounded (Silverman 2004: 46). Dalam proses pengumpulan datanya, penelitian ini menggunakan 4 metode: fotografi, observasi partisipatoris selama 7x dalam kurun waktu 14 hari (10 Juni - 24 
Juni 2018), wawancara terhadap 13 orang (sebagian besar ditemui di Lapangan Sempur), pencatatan lapangan, dan pengumpulan arsip historis.

\section{Hasil dan Pembahasan}

Taman Sempur berisi kompleks taman, yang terdiri dari lapangan utama dan beberapa taman spesifik dan lapangan, yaitu Taman Kaulinan, Taman Skateboard, Lapangan Utama, Lapangan Basket dan Taman Ekspresi. Masingmasing memiliki fungsi yang berbeda.

\section{Aksesibilitas Taman Sempur}

Posisi Taman Sempur terletak di wilayah pusat Kota Bogor, berhimpitan dengan Kebun Raya Bogor, dan hanya dipisahkan sebilah jalan Jalak Harupat. Tempat ini tak terlalu jauh dari Istana Bogor (Kepresidenan) dan Balaikota Bogor yang menunjukkan bahwa secara aksesibilitas Taman Sempur mudah untuk didatangi. Terdapat dua rute angkutan kota yang melewati Taman Sempur, yaitu o8A, jurusan Ramayana-Taman KencanaWarung Jambu, dan 03, jurusan Merdeka - Taman Kencana. Lokasi yang strategis menjadi modalitas utama Taman Sempur.

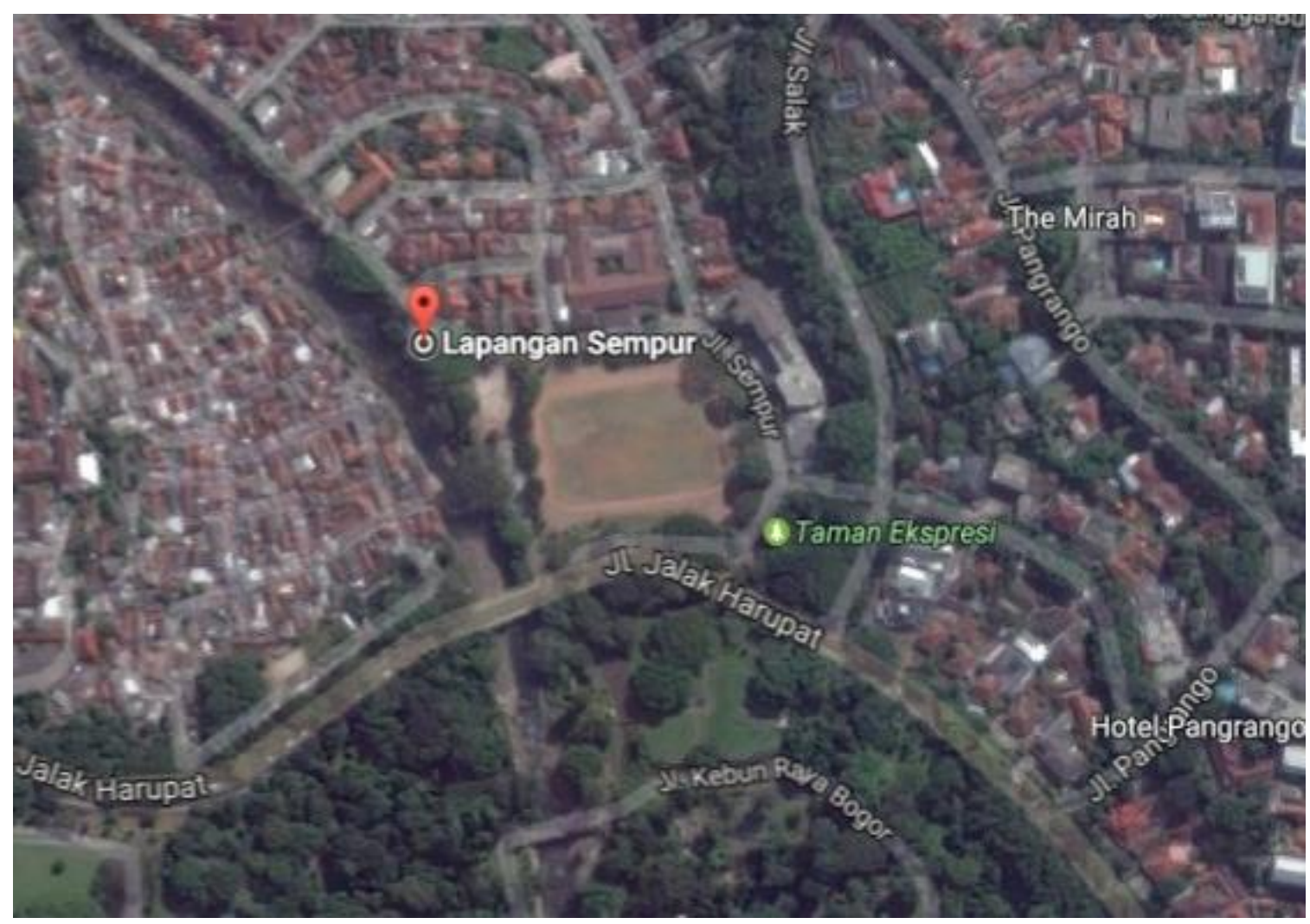

Gambar 1, foto satelit yang menunjukan lokasi Taman Sempur.

(Google Maps diakses, 8 Oktober 2018) 
Kontur jalan di sekitar Taman Sempur merupakan lerengan, yang menjadi hambatan bagi pejalan kaki. Begitupun jalan untuk mengakses Taman Sempur berupa lerengan.

"Satu-satunya kekurangan Taman Sempur, adalah saya harus membawa kendaraan pribadi." Roni, 32 tahun. Pengusaha.

Lerengan menjadi alasan sebagian warga Kota Bogor tidak berminat mengunjungi Taman Sempur.

"Aku sering lewat Taman Sempur, tapi hanya melihat dari atas saja. Melihat jalannya saja, sudah capek." Laroyba, 22 tahun. Mahasiswa.

"(Taman) Sempur tidak terlalu populer bisa jadi karena lokasinya walaupun dekat dengan jalan, tapi tetap terlihat agak jauh, karena turunan.” Ana, 20 tahun. Mahasiswa.

Terdapat tangga yang cukup curam sebagai jalan alternatif bagi pejalan kaki di salah satu sudut Taman Sempur. Selain itu, juga terdapat terowongan yang menghubungkan Taman Sempur dengan pedestrian di seberang jalan Jalak Harupat, terowongan Sempur yang kerap digunakan untuk berswa-foto tercium bau ammonia yang cukup tajam sebagai penanda indeksial tak sedikit orang yang membuang air kecil di sana.
Dalam persepsi sebagian warga Kota Bogor, lerengan di sekitar Taman Sempur adalah salah satu penghambat walaupun terlihat jelas pedestrian di sekitar wilayah Sempur tampak baik bila dibandingkan dengan lokasi lain di wilayah Bogor. Kota Bogor sendiri adalah wilayah yang memang secara kontur bergelombang. Topografi Kota Bogor berada pada ketinggian yang bervariasi di antara minimum 190 meter dan ketinggian maksimum 330 meter di atas permukaan laut.

Aksesibilitas atas ruang selalu bersifat mendua, terkait dimensi material (pedestrian, jalan, dll) yang memungkinkan Taman Sempur untuk diakses, dan habitus warga yang dapat mendorong mereka untuk berpartisipasi dan menjadi bagian dari publik. Terdapat pertanyaan yang lebih jauh dapat diajukan, yakni apakah 'keterbatasan akses' ini berkait dengan ruang dalam dimensi material atau habitus warga Kota Bogor yang tidak memiliki kultur berjalan kaki? Menimbang temuan Althoff (2017), masyarakat Indonesia berada pada posisi terendah dalam skala pejalan kaki dalam penelitian terhadap 111 negara lain di dunia. Rata-rata orang Indonesia hanya berjalan sebanyak 3, 513 langkah bila dibandingkan dengan rata-rata seluruh negara dengan 4,961 langkah. Diperlukan penelitian yang lebih spesifik untuk lingkup Kota Bogor guna menjawab pertanyaan tersebut. 


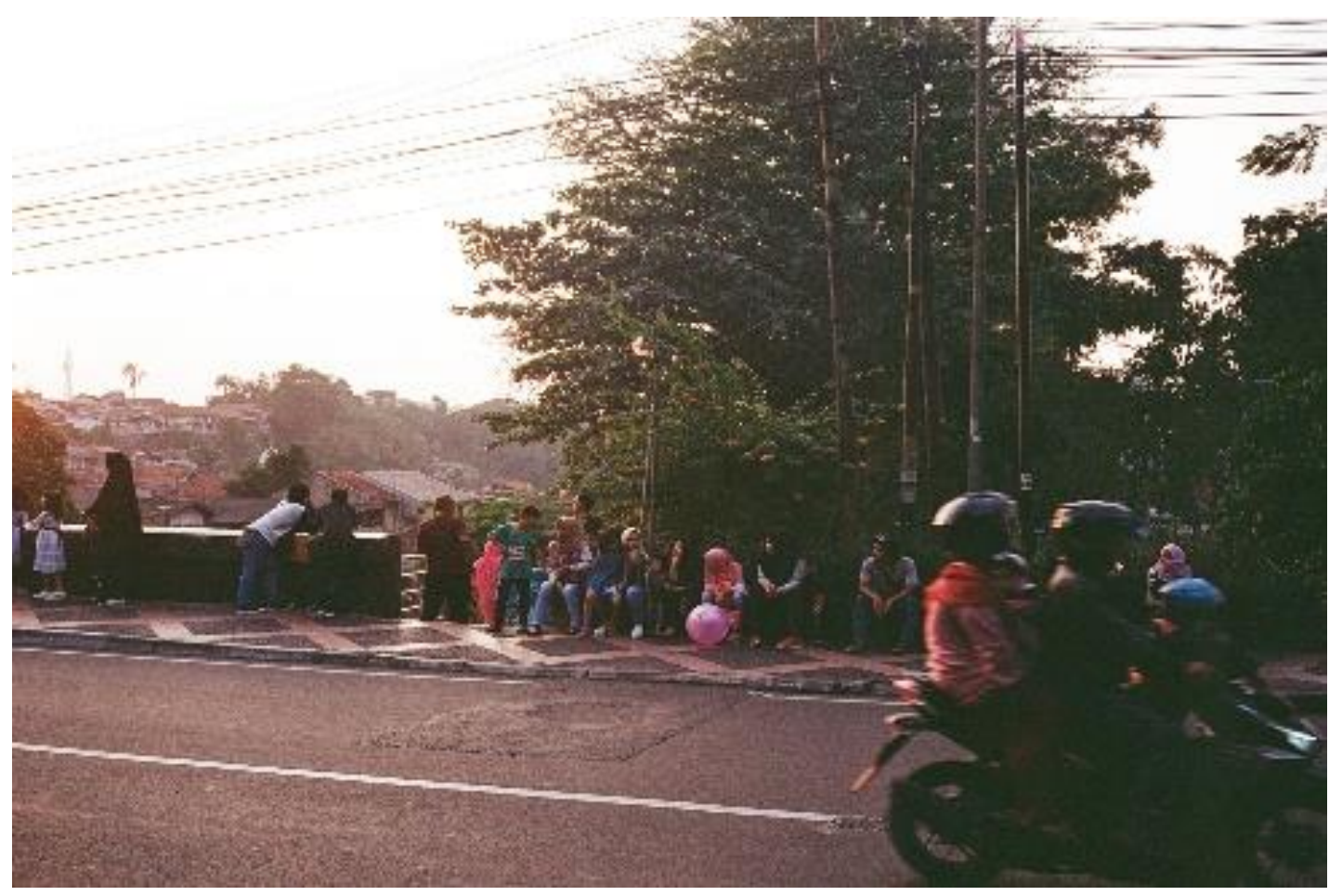

Gambar 2, Taman Sempur

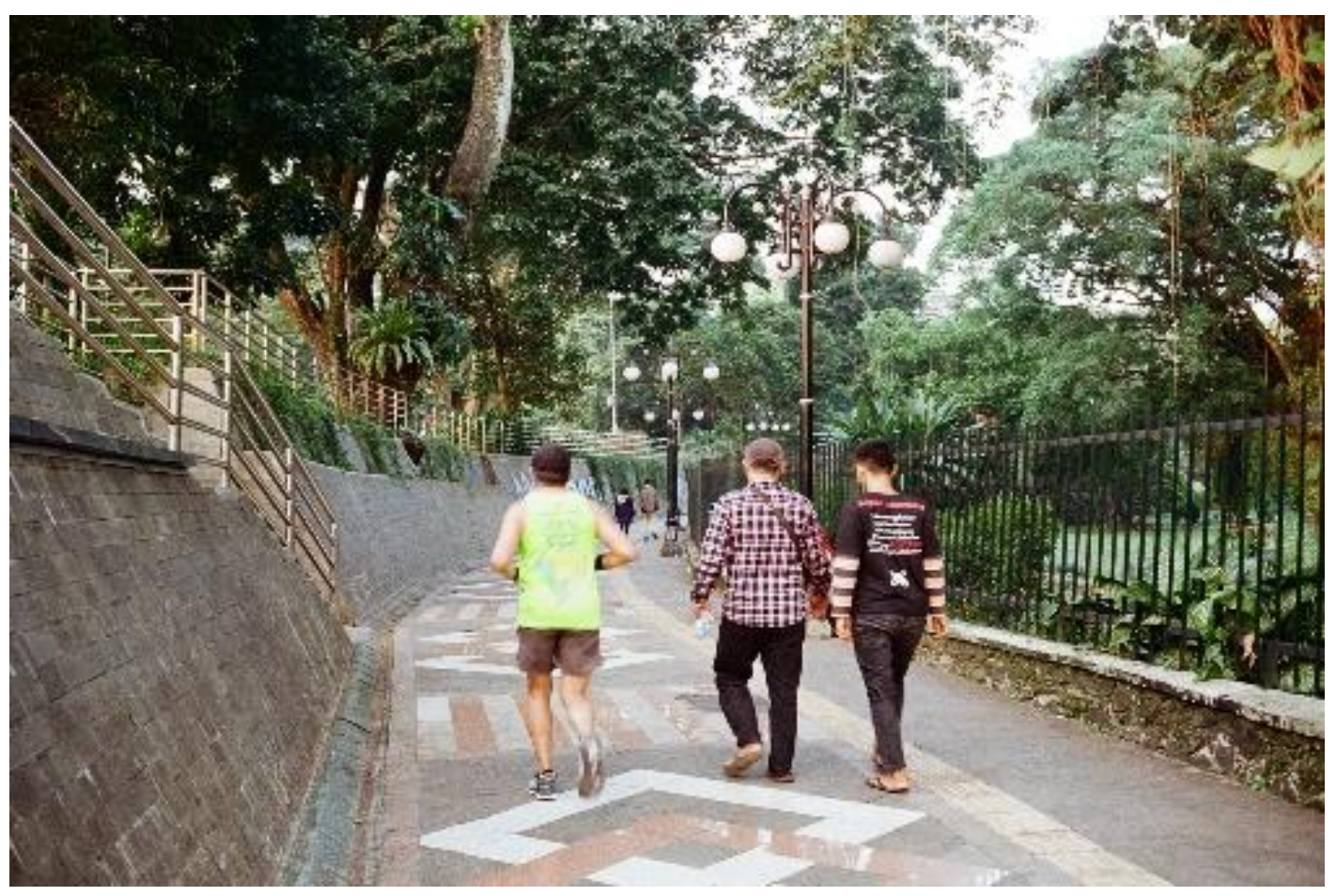

Gambar 3, Taman Sempur 
Lynch (1984) menjelaskan bahwa akses material/fisik adalah soal ketersediaan ruang bagi penggunanya untuk mengakses tanpa pengecualian, dan bersifat terbuka terhadap berbagai aktivitas/tindakan yang dipilih maupun tindakan spontan selama tidak mengganggu elemen publik yang lain. Terkait dengan habitus warga untuk berjalan kaki, pemerintah Kota Bogor berupaya mendorong dengan pengadaan fasilitas. Sejak 2017, Kota Bogor menargetkan menjadi kota ramah pejalan kaki. Namun, tentu saja, fasilitas sebagai modalitas tidak selalu berbanding lurus dengan habitus warga.
Sebagai ruang publik urban yang semestinya dapat diakses oleh semua orang dari berbagai latar masyarakat, fasilitas bagi warga disabel masih nihil. Belum ada jalur kuning untuk kaum disabel di trotoar di sekitar jalan Taman Sempur dan fasilitas khusus bagi pengguna kursi roda membuat modalitas Taman Sempur menjadi berjarak dengan ruang yang inklusif untuk para disabel. Seorang disabel yang kebetulan berada di Taman Sempur menuturkan sebagai berikutu.

"Hampir gak mungkin tuk saya untuk dapat datang sendiri ke taman ini, harus bersama keluarga dan membawa mobil. Tapi ya ini biasanya memang begitu di seluruh Bogor.” Aisyah, 58 tahun, istri pensiunan - tuna netra

\section{Taman Kaulinan dan Pendidikan Politik dan Demokrasi}

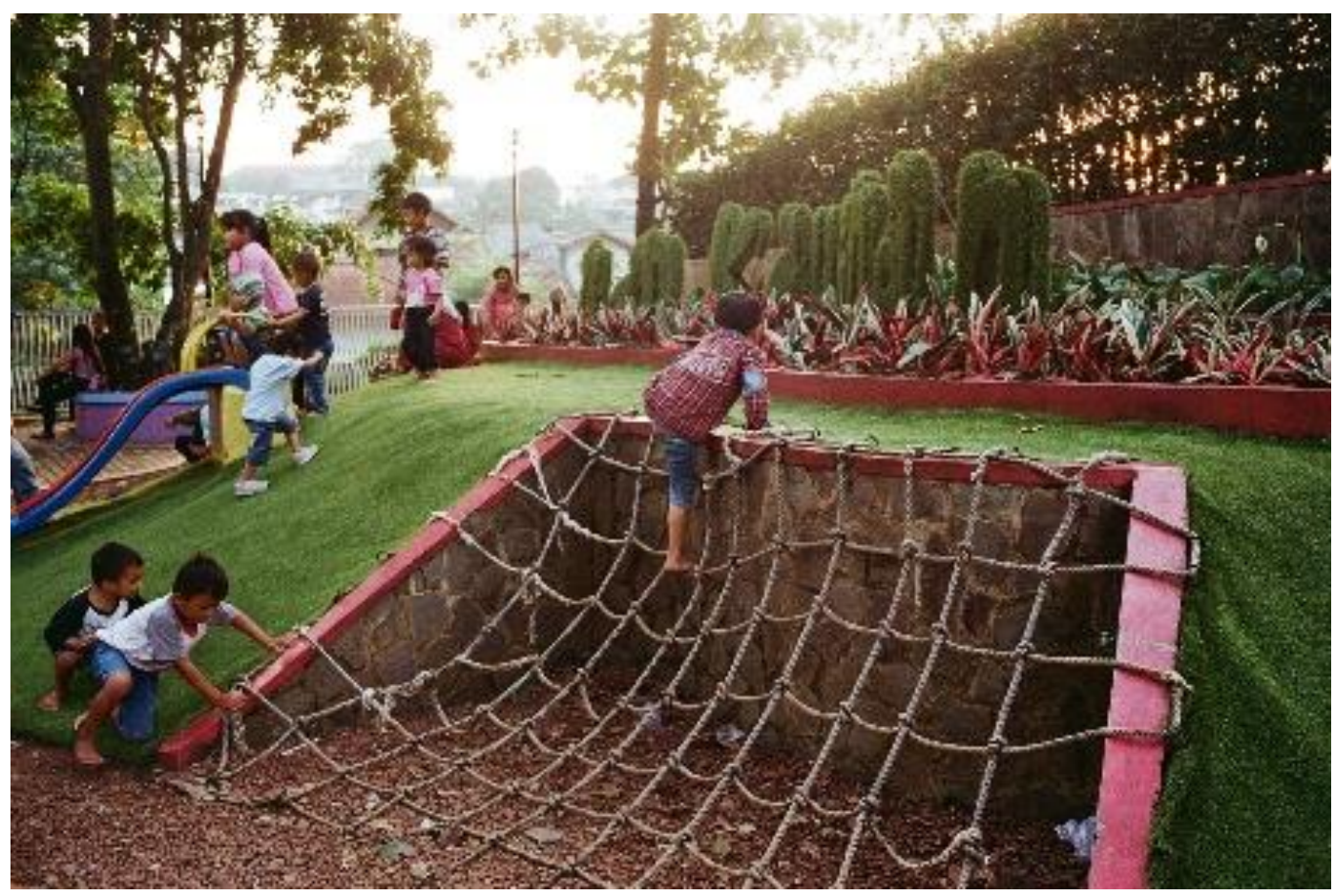

Gambar 4, Taman Kaulinan 


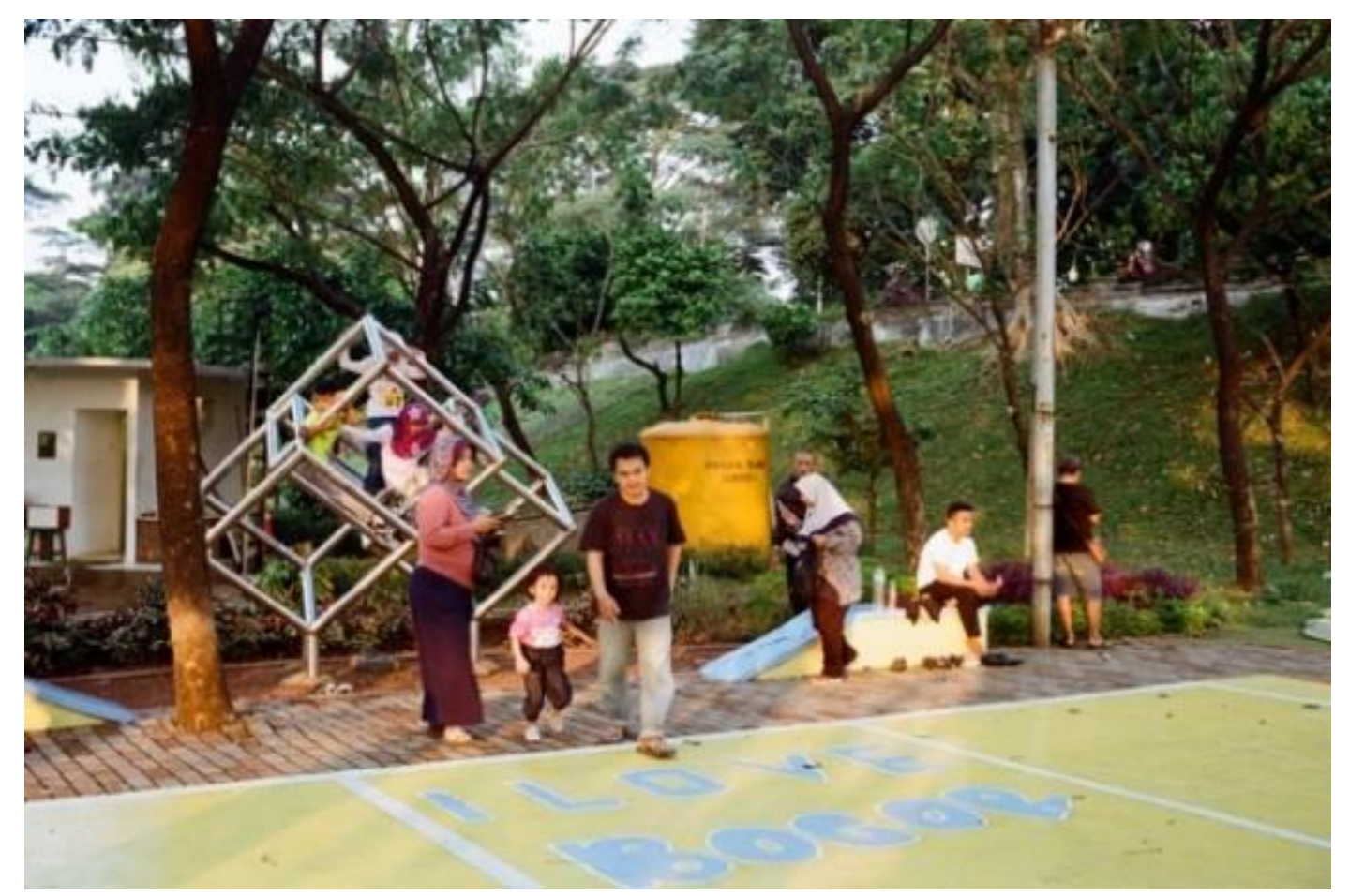

Gambar 5, Taman Kaulinan

Dari modalitas yang nampak, kita dapat melihat raut wajah senang gembira dan gestur atraktif anak-anak sedang menikmati wahana permainan yang tersedia di Taman Kaulinan. Setiap sore, kita dapat melihat anak-anak bermain dengan volume puncak pada akhir pekan dan hari libur. Sebagian anak-anak terlihat menikmati permainannya sendiri bersama sebayanya, yang kadang tidak saling kenal satu sama lain. Sebagian yang lain, masih didampingi orang tua. Fasilitas yang terletak di bagian barat Taman Sempur ini memang ditujukan khusus untuk arena permainan anak-anak. Wahana yang ada diwarnai dengan warna cerah: merah, biru, kuning, hijau, warna yang memiliki relasi simbolik dengan keceriaan anak-anak. Terdapat wahana berupa tiga kubus saling tersusun yang terbuat dari besi stainlesteel dan dapat dinaiki. Wahana tersebut memiliki relasi simbolik dengan matematika, dan memberikan nunsa saintifikal melengkapi wahana lain yang lebih terkesan dekat dengan "alam".
Dalam konteks pedagogis, kita dapat melihat bagaimana playscape yang terdapat di Taman Kaulinan menjadi modalitas dalam relasinya pada peningkatan aktivitas fisik anak-anak, dan memicu kemampuan motorik. Walaupun terdapat rumput sintetis yang menjadi bagian taman tersebut, playscape yang berlatar alam dengan pepohonan dan rumput akan mendekatkan anak pada aktivitas yang melibatkan alam, yang berarti anak-anak akan jauh lebih mudah mencintai lingkungan ketimbang beraktivitas di dalam ruangan (Carr, 2014). Selain itu, kebersamaan anak-anak untuk saling bermain satu sama lain mengajarkan mereka sejak dini tentang kebersamaan, berbagi fasilitas, dll.

Tidak adanya pembeda antara kelas sosial, dan latar belakang yang lain dalam mengakses wahana dapat menjadi pelajaran politik yang baik untuk anakanak, dan tidak hanya diajarkan secara normatif, tapi pendidikan inklusif yang aktif terfasilitasi oleh keberadaan Taman 
Kaulinan sebagai ruang publik urban yang ramah terhadap anak-anak. Selain menjanjikan aktivitas yang menyenangkan, wahana bermain juga merupakan medan wacana yang formasional, normatif, dan didaktik dan menunjukkan performativitasnya sebagai minatur public sphere. Tempat di mana aturan sipil hidup bersama diajarkan, pengaturan prilaku untuk memahami dan bernegosiasi satu sama lain, dan memacu untuk menaati peraturan-peraturan yang ada, tapi sekaligus mengikuti fantasi dan imajinasi atas permainan. Taman Kaulinan sebagai wahana bermain anakanak adalah representasi sekaligus wahana eksperimentasi pendidikan visi politik dan demokrasi sejak dini (Stutzin, 2015).

Walaupun diperlukan pengawasan oleh orang tua untuk menghindari risiko cedera fisik, dapat dilihat orang tua yang ada turut mendorong anak-anak mereka menaati norma sosial yang ada. Orang tua melerai anak-anak yang memperebutkan giliran atas wahana yang ada, dan tidak nampak orang tua yang membatasi interaksi antara satu anak dengan anak yang lain.
"Anak-anak saya senang bermain di sini ... Si-Kakak yang menemani dan njagain adiknya. Saya biasanya hanya duduk saja, kadang ditemani suami.” Rosa, 31 tahun. Ibu Rumah Tangga.

Taman Kaulinan secara spesifik tidak dibangun dari dana pemerintah semata, tapi diberikan oleh PT Sumber Alfaria Trijaya Tbk (Alfamart Alfafimidi) melalui program Corporate Social Responsibility (CSR) yang bekerjasama dengan Yayasan Berani Bhakti Bangsa. Walaupun berasal dari pihak swasta, tidak terlalu terlihat dan terasa intervensi modal terhadap aktivitas yang terdapat di Taman Kaulinan khususnya, ataupun Taman Sempur sebagai wadah yang lebih besar. Satu-satunya yang dapat dirasakan, setelah mengetahui bahwa aliran modal dari pembangunan Taman Kaulinan berasal dari perusahaan induk waralaba Alfamart, adalah kita dapat mengidentifikasi warnawarna dominan yang digunakan untuk menghiasi Taman Kaulinan sejajar dengan komposisi warna yang menjadi simbol Alfamart: merah, kuning dan biru.

\section{Gaya hidup Urban dan Olahraga: Taman Skateboard dan Basket}

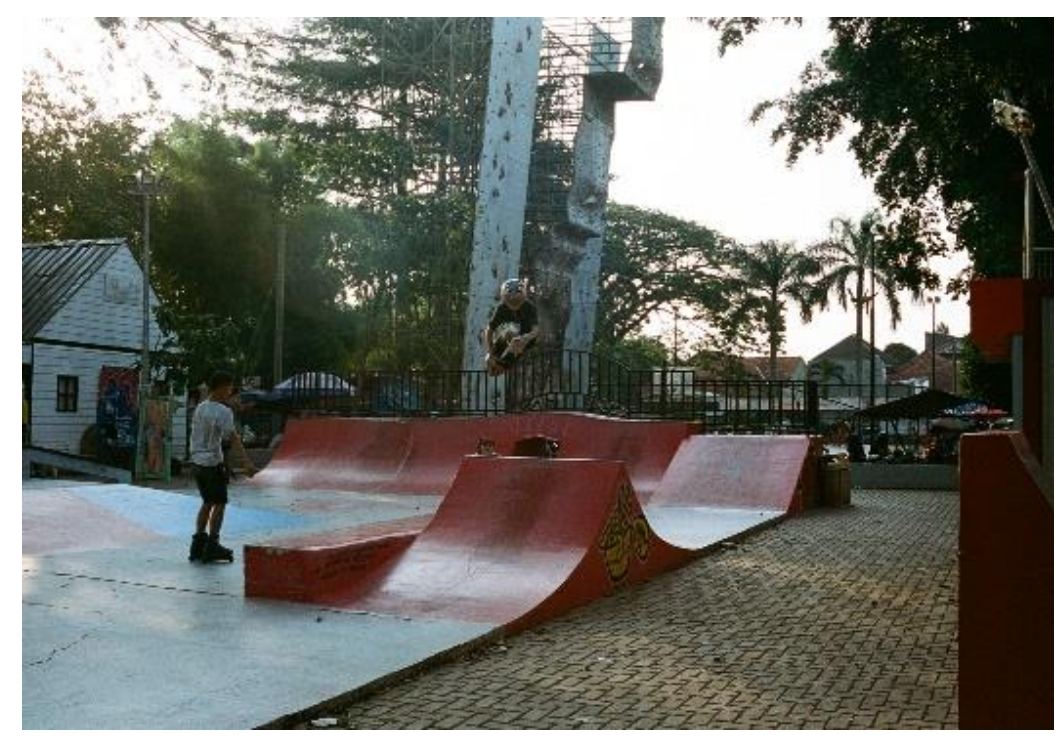

Gambar 6, Taman Skateboard 
Hampir setiap sore selalu ada yang mengakses taman skateboard yang terletak tepat di sebelah Taman Kaulinan. Mereka yang turut serta bermain rata-rata berusia muda, di bawah 30 tahun. Tidak hanya skateboard, terdapat juga pengguna rollerblade, sepatu roda dan sepeda bmx. Wahana yang disediakan cukup lengkap karena jarang wahana khusus yang ditujukan untuk permainan yang sering dianggap sebagai salah satu olahraga dan hobi yang identik dengan kelas menengah dan gaya hidup urban tersedia.

Terdapat beberapa komunitas yang rutin bergiat di wahana ini, salah satunya adalah Komunitas Bogor Independen Skateboard. Selain mereka yang berasal dari komunitas, terdapat juga individuindividu yang memanfaatkan wahana tersebut. Mereka melakukan bergantian, dan nampak saling memperhatikan, mempelajari, dan memuji trick satu sama lain walaupun sebagian dari mereka tidak saling mengenal.

Sebelumnya, pada 2016, telah diselenggarakan kompetisi skateboard nasional yang pesertanya banyak berasal dari Jabodetabek. Sebelum kompetisi tersebut, walaupun terdapat komunitas yang cukup besar penyuka olahraga skateboard, hampir tidak pernah diselenggarakan kompetisi skateboard level nasional yang diselenggarakan di Kota Bogor. Hal ini menunjukkan bahwa taman skateboard berhasil menjadi wadah bagi komunitas untuk menyalurkan hobinya.

"Saya nggak ikut komunitas di sini ... Tapi kalau dilihat bermain di sini menyenangkan, terutama karena di sini saya bisa melihat orang yang lebih jago dari saya, kadang sambil sharing juga, padahal saya nggak kenal." Andre, 20 tahun. Mahasiswa

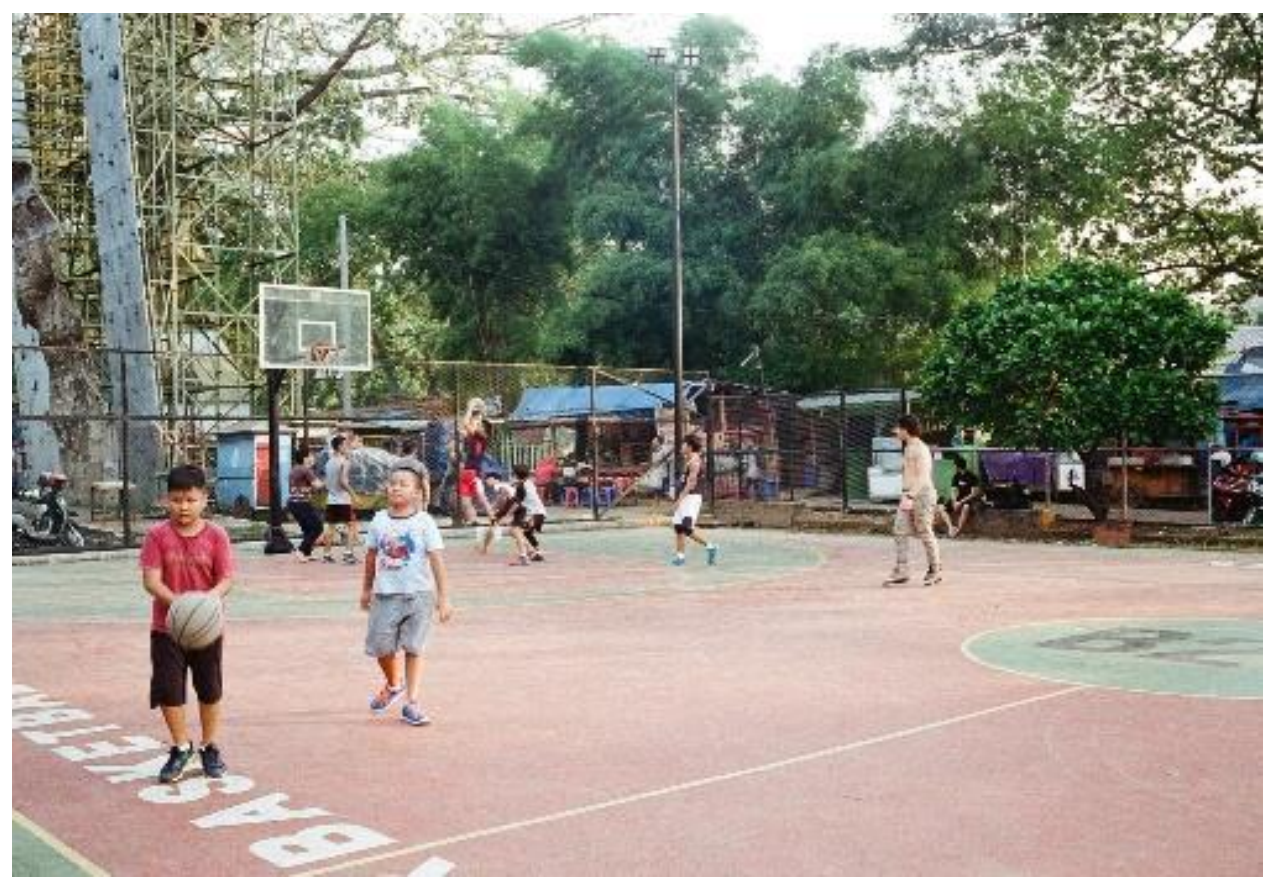

Gambar 7, Lapangan Basket 
Serupa dengan taman skateboard, lapangan basket yang tersedia di Taman Sempur memfasilitasi masyarakat untuk menggunakannya.

Penggunanya kebanyakan adalah remaja sekolah menengah dan mahasiswa yang berasal dari berbagai sekolah dan universitas. Tak jarang, mereka yang pekerja juga menggunakannya dan ikut bertukartanding, biasanya di akhir pekan. Seringkali, pertandingan tidak diselenggarakan satu lapangan penuh, 3 lawan 3 atau 4 lawan 4 yang memanfaatkan setengah lapangan sehingga tak jarang dalam satu waktu terdapat dua pertandingan dengan memanfaatkan satu lapangan yang sama. Tujuannya untuk mengakomodasi lebih banyak pemain. Walaupun begitu, seringkali tetap banyak pemain yang menganggur, menunggu giliran untuk bermain.

"Di sini, saya sering bermain dengan yang seketemunya. Saya sendiri datang bersama bekas teman SMA saya dulu, Regina Pacis. Sekarang saya kuliah di Jakarta, kalau pulang ke Bogor, saya sering ngajak teman saya main basket di sini." Raymond, 19 tahun. Mahasiswa.

Terkadang, anak-anak yang usianya di bawah remaja turut bermain, tapi beberapa kali terlihat dipinggir, dan sekadar belajar men-dribble bola. Terlihat mereka ingin ikut menggunakan ring basket, tapi tidak mendapatkan giliran karena telah didominasi oleh mereka yang lebih dewasa dan berbadan lebih besar. Dari kondisi-kondisi tersebut, kita dapat melihat fasilitas lapangan basket di Lapangan Sempur terasa kurang bila dibandingkan dengan kebutuhan warga, terutama pada akhir pekan.

Di antara lapangan basket dan taman skateboard, terdapat tempat latihan panjat dinding yang cukup tinggi. Selama tujuh kali observasi, tempat latihan tersebut hanya sekali digunakan. Walaupun berdasarkan pengakuan pengunjung yang cukup rutin di Taman Sempur, sarana tersebut cukup sering digunakan.

"Sering kok dindingnya dipakai orang manjat, untuk latihan. Sepertinya sih anak-anak pencinta alam." Caesar, 26 tahun. Pekerja dan mahasiswa.

Pada saat malam hari, daerah di sekitar taman skateboard dan lapangan basket tetap hidup. Hampir 24 jam, selalu terlihat ada aktivitas di sana. Biasanya, anak-anak yang sekadar nongkrong, tapi terkadang saat malam terlihat anak-anak muda mengonsumsi minuman beralkohol. Kadang juga, mereka terlihat mabuk hingga terkapar.

"Kebetulan kalau aku biasa nongkrongnya di dekat lapangan basket dan tempat skate, nah disitu kegiatannya hidup 24 jam, sayangnya kalau malam suka ada yang mabu-mabu. Azmi, 24 tahun. Pekerja. 
4. Pedestrian, Joggingtrack dan Lapangan Utama: Public Space dan Tuntutan Empati

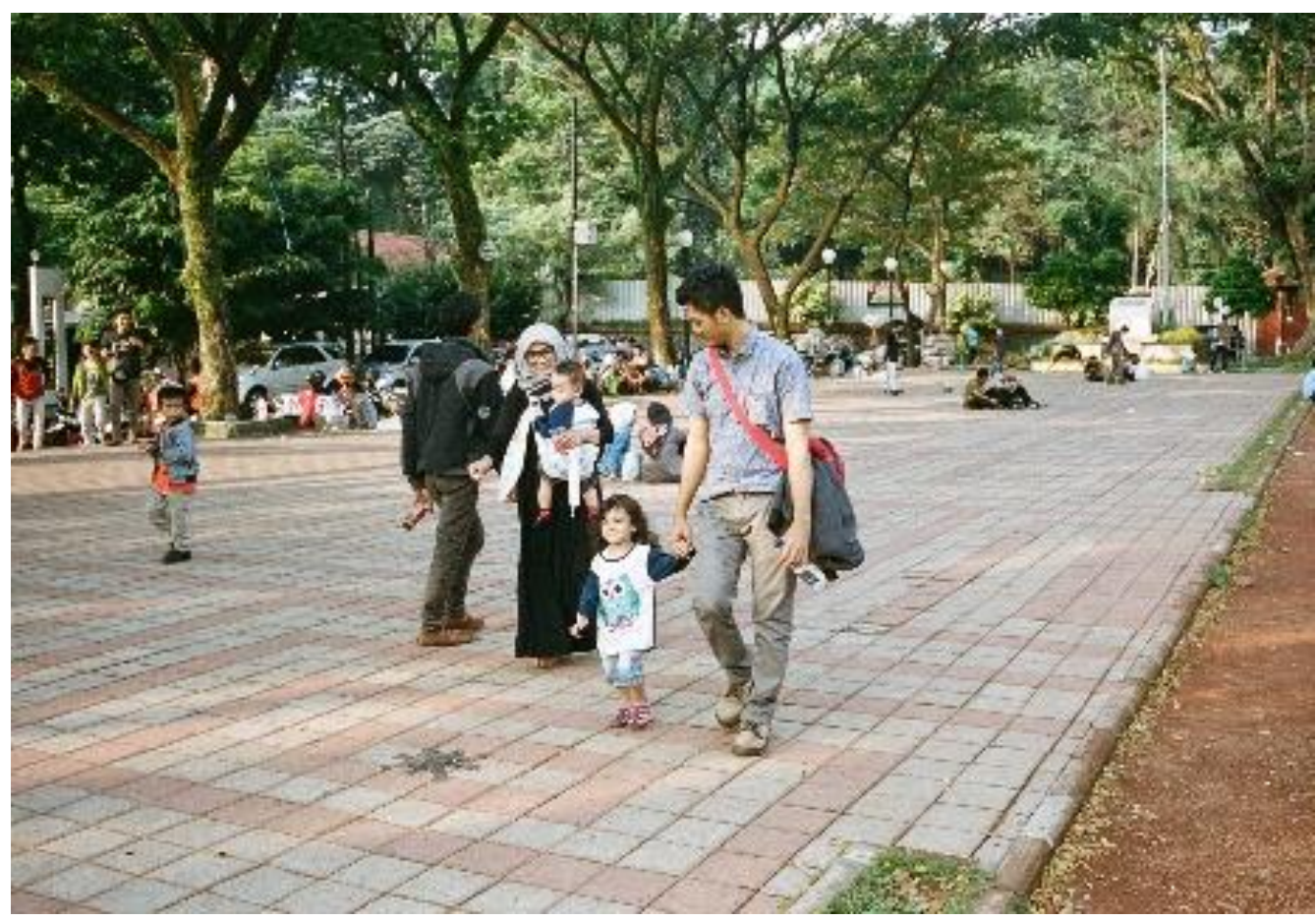

Gambar 8, Pedestrian, Joggingtrack dan Lapangan Utama

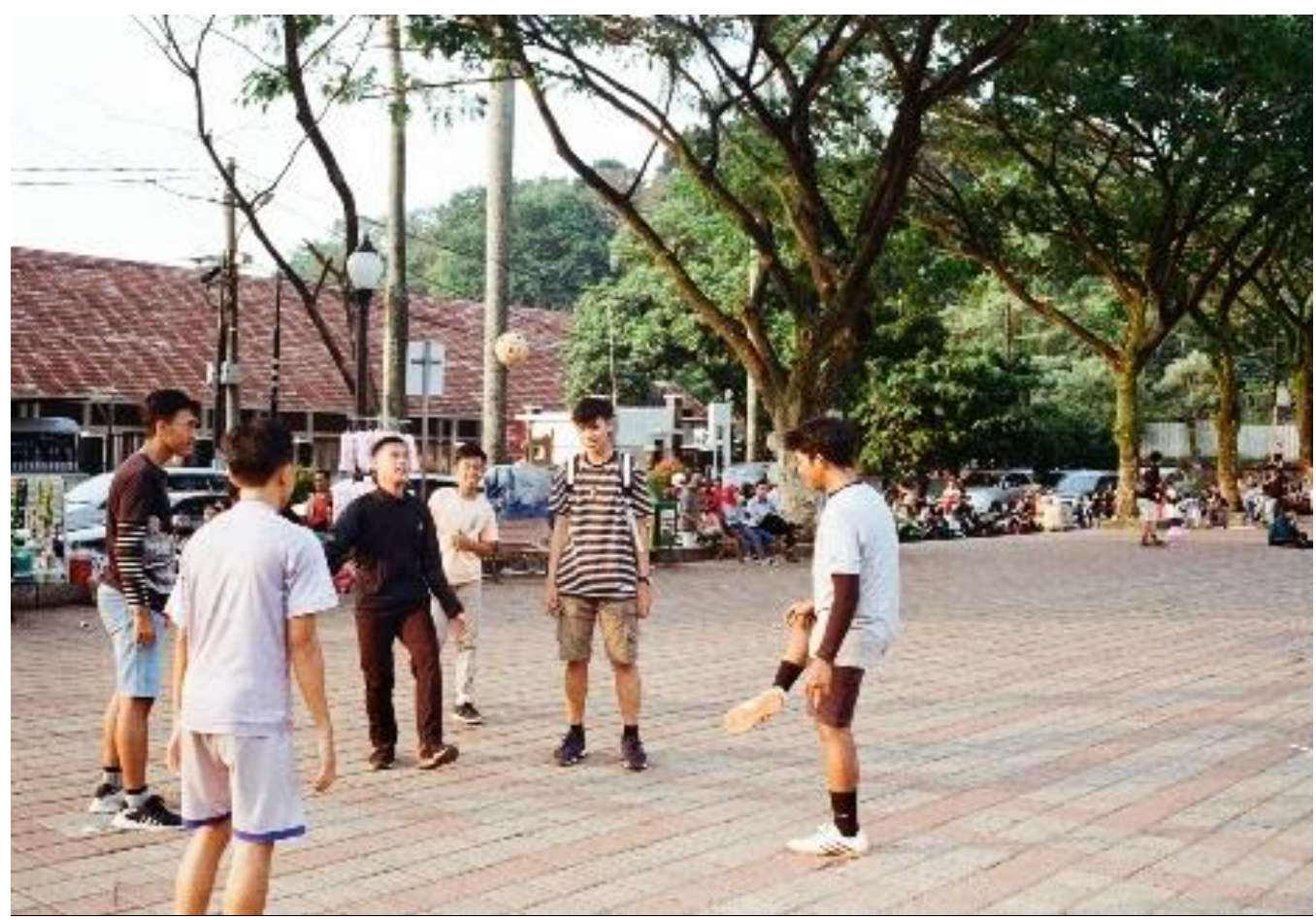

Gambar 9, Pedestrian, Joggingtrack dan Lapangan Utama 
Di bagian utara Taman Sempur, terdapat pedestrian yang di pinggirnya terdapat pohon-pohon yang relatif muda bila dibandingkan dengan pohon-pohon lain di wilayah Taman Sempur. Pedestrian tersebut tepat berada di samping jogging track, yang membuatnya menjadi lokasi transit atau istirahat sejenak mereka yang berlari.

Pedestrian digunakan orang untuk berjalan bersama keluarga, dan sebagian remaja menggunakannya untuk bermain juggling bola, anak-anak bermain mainan yang juga dijajakan di sekitar pedestrian oleh pedagang-pedagang yang menggunakan bakulan berupa balon sabun, balon udara, maupun bola plastik. Terlihat beberapa orang dengan acak dan spontan duduk di tengah ataupun pinggir pedestrian. Raut wajah yang nampak sangat beragam, garis besar yang dapat ditarik dari modalitas yang nampak adalah sebagian besar menikmati pedestrian di Taman Sempur dengan aktivitas kelompoknya masing-masing. Walaupun terlihat banyak orang beraktivitas bersamaan di pedestrian, kebanyakan aktivitas adalah aktivitas parsial dalam grup-grup kecil, entah mereka bersama keluarga maupun bersama teman-teman.

Aktivitas di pedestrian hampir tidak pernah sepi pada saat sore hari, tepatnya setelah matahari lingsir. Pada siang hari, matahari terasa menyilaukan, warna abu-abu, dan merah muda dari paving-block terasa memantulkan cahaya yang membuat hampir tidak mungkin orang-orang yang bermain merasa nyaman. Ada pertanyaan yang dapat diajukan, mengapa pedestrian tersebut harus berupa pavingblock, dan bukan rumput otentik?

\begin{abstract}
"Sebenarnya duduk di sini karena terpaksa $A$ ' di sini panas dan gak banyak pohon rindangnya. Karena kursi yang ada di Taman Sempur hanya ada di seberang sana (sambil menunjuk), dan jumlahnya gak banyak. Biasanya, sudah ditempati sama orang pacaran dan ibu-ibu yang bawa anak. Jadi, ya sembarang duduk saja. Bakalan lebih enak sebenarnya kalo di bagian sebelah sini juga ada bangkunya, jadi bisa duduk-duduk" Dede, 14 tahun. Pelajar.
\end{abstract}

Pedestrian sebenarnya mempunyai kelebihan berupa lahan terbuka tanpa ada struktur yang menghalangi yaitu lahan tersebut dapat digunakan dengan bebas untuk melakukan apa saja. Beberapa kali terlihat remaja bermain permainan tradisional seperti bentengan ataupun gobaksodor atau ada juga anak-anak yang berlarian mengejar balon sabun tanpa mengganggu pengguna yang lain karena tempat yang begitu terbuka.

Lahan pedestrian ini tampak optimal sebagai public space, tapi tidak dapat dikatakan memiliki fungsi penuh sebagai public sphere mengingat dimensi politik yang terkontestasi di sebidang lahan ini cukup minim, selain soal bagaimana hidup berdampingan. Di sisi lain, temu komunitas atau diskusi-diskusi maupun konsolidasi organisasi sosial yang memiliki dimensi politik, biasanya dilakukan di Taman Ekspresi yang akan dijelaskan di bagian lain narasi ini. Dalam paparan Hou (2010), "ruang publik telah menjadi bagian penting kota dan budaya urban...Mereka memberikan kesempatan untuk berkumpul, bersosialisasi, rekreasi, festival, serta protes dan demonstrasi”. Pedestrian Taman Sempur memberikan sebagian besar contoh budaya urban tersebut, bahkan festival kuliner Ikan telah diselenggarakan di Taman Sempur pada tanggal 24 September 2017 dengan 
melibatkan puluhan UMKM, dan 1000 pelajar SD, SMP se-Kota Bogor. Namun, terdapat hal yang tetap absen, yaitu ekspresi vulgar dari politik akar rumput, protes dan demonstrasi. Hampir tidak pernah terjadi di mana Taman Sempur digunakan oleh warga untuk protes dan demonstrasi, mengingat jaraknya yang dekat dengan Balaikota dan Istana (Kepresidenan) Bogor. Kedua aktivitas itu lebih sering mengarah secara langsung lokasi pusat pemerintahan.

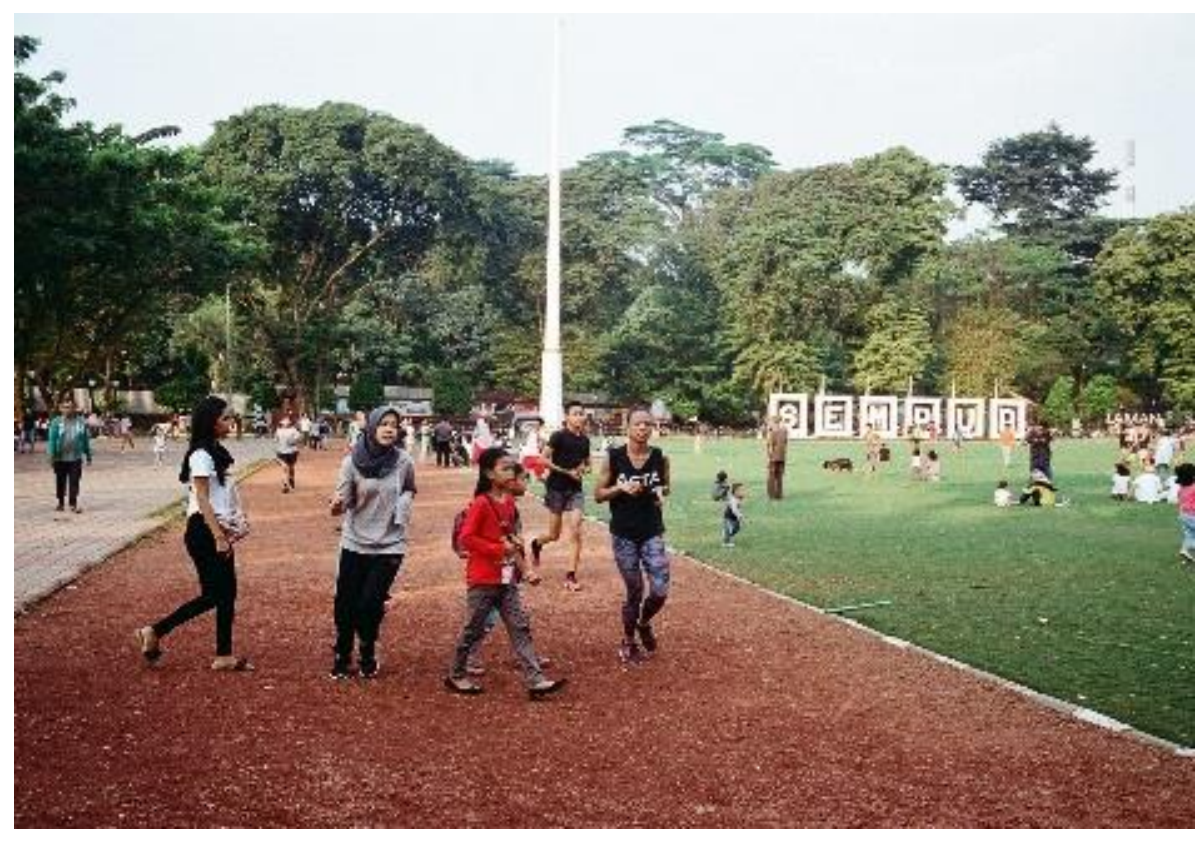

Gambar 10, Pedestrian, Joggingtrack dan Lapangan Utama

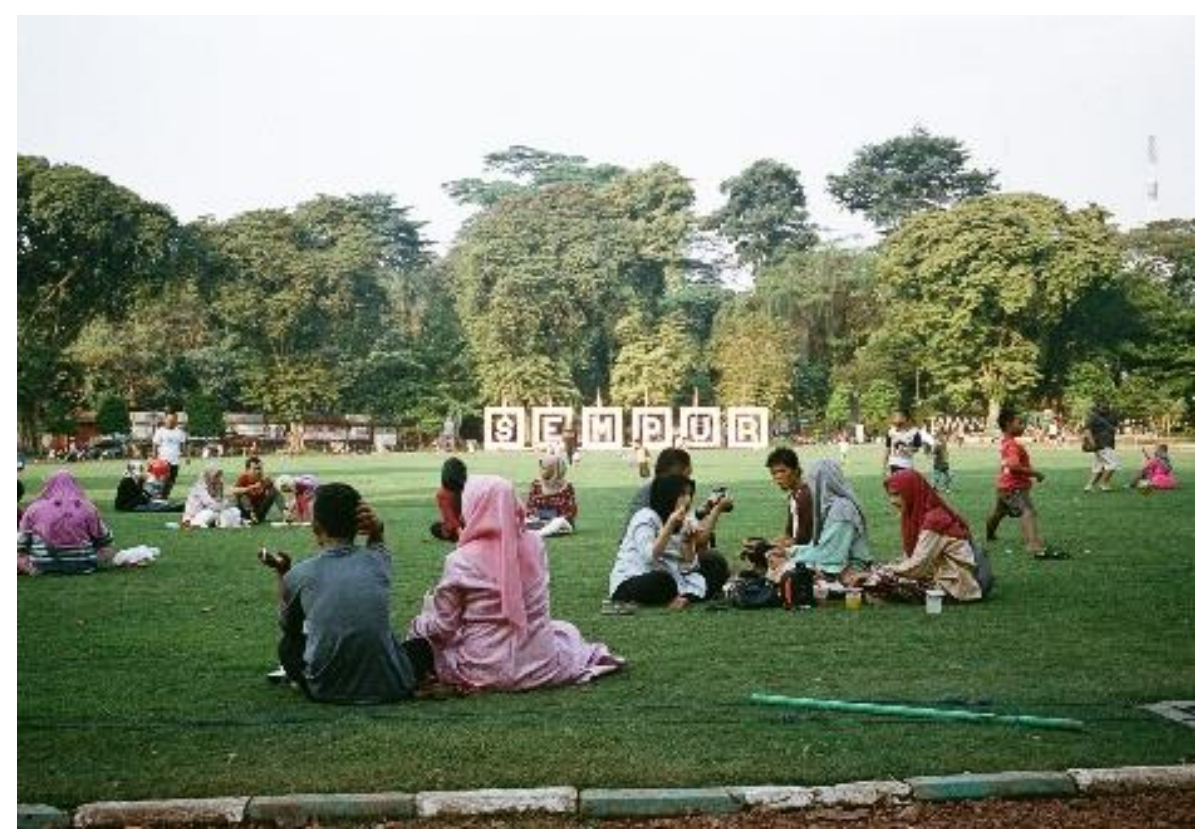

Gambar 11, Pedestrian, Joggingtrack dan Lapangan Utama 
Bagian utama Taman Sempur tersusun dari jogging track yang mengelilingi lapangan rumput yang terletak di tengah sebagai sentral lapangan Sempur, dan memiliki tiang bendera penanda dapat digunakan sebagai lapangan upacara. Pada Bagian Timur, terdapat aksara yang menyusun kata "SEMPUR", kata tersebut masing-masing berdiri sendiri dengan kotak yang mengelilinginya.

Jika dilihat dimensi arsitektural Taman Sempur, maka tampak bermasalah karena untuk dapat mengakses lapangan rumput, pengunjung harus melewati jogging track terlebih dahulu. Ini seringkali mengganggu yang sedang beraktivitas jogging. Berkali-kali, mereka yang menyeberang ke lapangan rumput tidak memperhatikan sekitar sehingga mengganggu yang sedang beraktivitas jogging. Hal ini menunjukkan kurangnya empati satu sama lain di antara para pengguna bagian utama Taman Sempur.

Empati ini juga patut dipertanyakan ketika kita memerhatikan ke lapangan utama Taman Sempur. Pada saat ramai, kita bisa melihat orang-orang yang menyalakan dan menghisap rokok di atas rumput sembari bersantai tanpa menghiraukan sekitar. Meskipun terbuka namun, anak berlarian menyisir setiap bagian lapangan yang memungkinkannya turut menghisap asap rokok. Sebagai public space dan diupayakan dapat juga menjadi public sphere, lokasi utama Taman Sempur seharusnya dapat bebas dari asap rokok, dan Taman Sempur memiliki wilayah atau ruang khusus bagi perokok. Studi Tan (2012) menunjukkan bahwa bau asap rokok dapat berimplikasi terhadap ketidaknyamanan sebagian pengguna ruang publik sehingga menciptakan segregasi. Tidak hanya terkait etika dan etiket dalam ruang kebersamaan, keberadaan rokok juga berisiko menghilangkan inklusivitas Taman Sempur.

"Oh merokok di sini gak boleh ya? Saya merokok karena gak keliatan ada aturannya." Dudi, 29 tahun, Pekerja.

Taman Sempur digunakan oleh mereka yang berasal dari berbagai lapisan masyarakat. Hal tersebut dapat dilihat dari penanda-penanda yang melekat pada tubuh pengguna, seperti pakaian, perhiasan, barang-barang yang digunakan. Sebagian menggunakan lapangan untuk bermain bersama keluarga inti maupun membawa keluarga besar, kerabat ataupun komunitasnya.

Selama dua kali dalam tujuh kali kunjungan, terlihat pertandingan sepakbola dengan bertelanjang kaki yang dilakukan anak remaja dan mereka yang berusia lebih tua dengan bergawangkan sepatu atau sandal. Sebagian pemain saling kenal satu sama lain, tapi ada beberapa yang memang diajak di tempat, dan baru mengenal di permainan itu. Permainan tidak dilakukan dengan serius mengingat keterbatasan tempat, dan banyaknya orang yang duduk-duduk. Saat bola mendekati pengguna yang lain, para pemain cenderung memelankan pergerakannya agar bola tidak mengganggu lainnya.

"Di sini, enak untuk main sepakbola karena lapangannya besar. Saya jadi ingat waktu jaman SMP dan SMA karena bisa main di lapangan gede sebelah Karya Bakti. Kalau sekarang jika mau main bola harus nyewa lapangan futsal, di sini lapangannya gede, rumputnya empuk dan pemainnya bisa banyak." Mahfud 29 tahun. 
Anak-anak di usia sedang juga terlihat menciptakan permainan sepakbolanya sendiri dengan skala lebih kecil. Anak-anak kecil yang tergolong balita, akan diletakkan di bagian pinggir, atau bagian lain lapangan yang digunakan untuk permainan bola, hal yang meminimalisir risiko terkenanya bola.

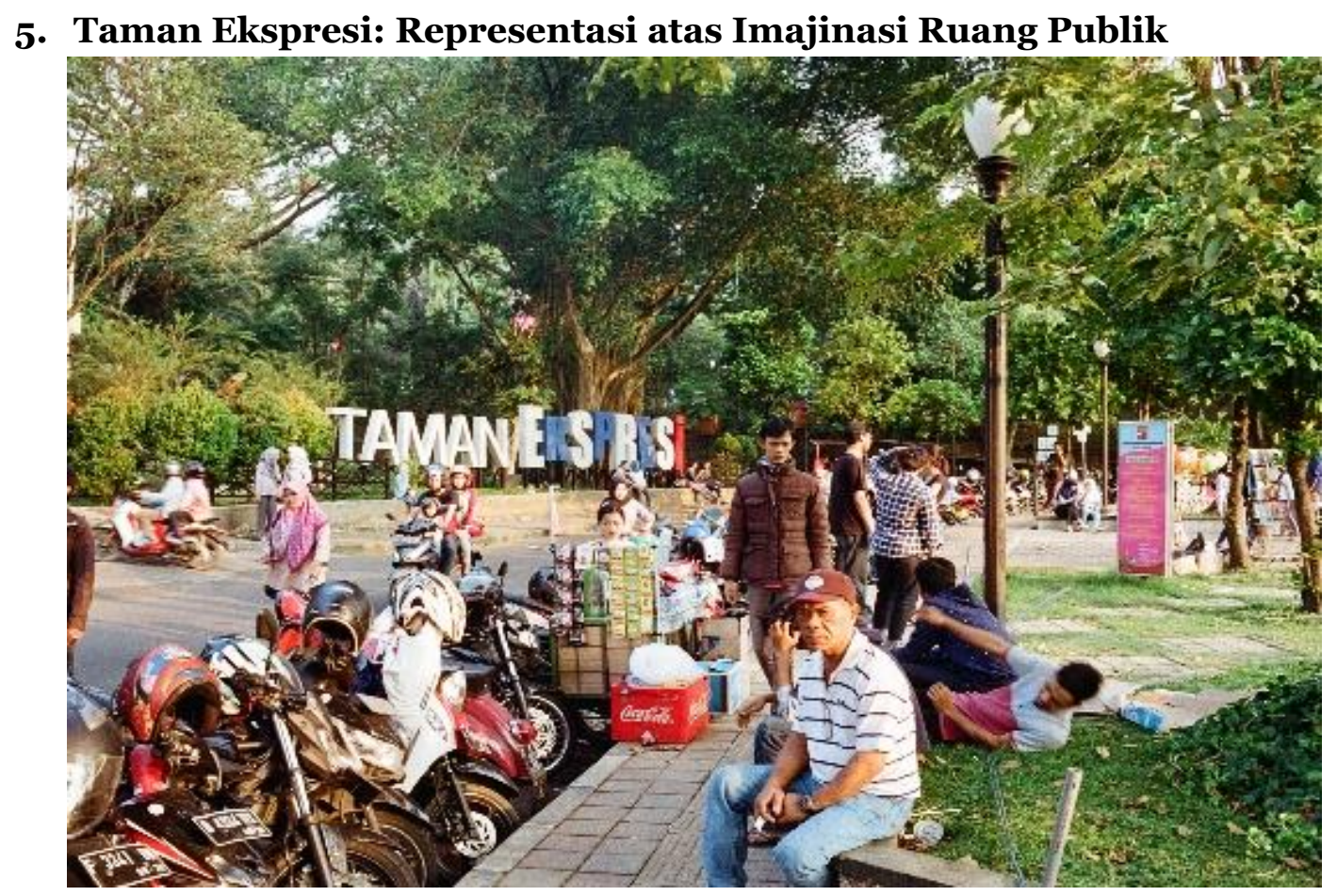

Gambar 12, Taman Ekspresi

Pada bagian barat wilayah Taman Sempur, terdapat Taman Ekspresi yang didesain dengan bentuk arsitektur, teater terbuka. Bagian tengah Taman Sempur memiliki alas yang berasal dari batu andesit dengan undakan-undakan yang berfungsi sebagai tempat duduk bagi penonton. Taman Ekspresi adalah miniatur amphitheatre of Pompeii yang dapat digunakan mendiskusikan apapun. Tempat yang memiliki potensi politik paling kuat bila dibandingkan dengan bagian lain Taman Sempur.

Dana yang dihabiskan untuk membangun Taman Ekspresi adalah Rp 2 miliar dari dana APBD Bogor tahun anggaran 2015, dan digunakan untuk membenahi lahan seluas 3.000 meter persegi (Laily, 2015). Taman Ekspresi adalah tempat yang menjadi andalan bagi kegiatan-kegiatan komunitas seperti pagelaran kesenian dan pertunjukan musik. Pada hari-hari biasa, digunakan untuk pertemuan komunitas-komunitas. Tempatnya yang cukup besar membuat komunitas-komunitas yang ada dapat berbagi. Walikota juga memerbolehkan Taman Ekspresi digunakan untuk berdemonstrasi walaupun hal tersebut nihil dilakukan di sasana tersebut. Tidak perlu izin untuk mengakses Taman Ekspresi kecuali bila ingin menyelenggarakan acara yang cukup besar, dan akan menyedot perhatian warga.

"Aku pernah sekali-dua kali kumpul komunitas di Taman Ekspresi ... Di sana juga sering dipakai untuk orang latihan dance" Syifa, 24 tahun. Mahasiswa S2 
"Dulu sebelum ada Taman Ekspresi, pas Aku SMP ini isinya pohon-pohon tua gitu, biasanya anak-anak SMP pada mesum. Sekarang jadi lebih nyaman dan digunakan untuk aktivitas komunitas.” Azmi, 24 tahun. Pekerja.

Terdapat dua kekurangan Taman Ekspresi, yaitu terkait penerangan yang apabila malam masih tampak gelap. Akibatnya, aktivitas pada waktu malam atau matarhari tenggelam tidak sebesar pada siang hari. Kekurangan yang lain adalah masalah kebersihan WC.

"Pencahayaan di Taman Ekspresi kalau menurut aku masih cenderung gelap di malam hari sehingga mengurangi rasa aman." Syifa, 24 tahun. Mahasiswa S2.

"WC sekarang ada dua kan ya, yang dari Pemerintah Kota, satu di Taman Ekspresi, satu lagi di tempat main skateboard. Cukup rutin dibersihkan, tapi mungkin untuk mereka yang sensitif tetap terasa kotor. Andre, 20 tahun. Mahasiswa.

\section{Kontestasi Dimensi Material dan Habitus Warga}

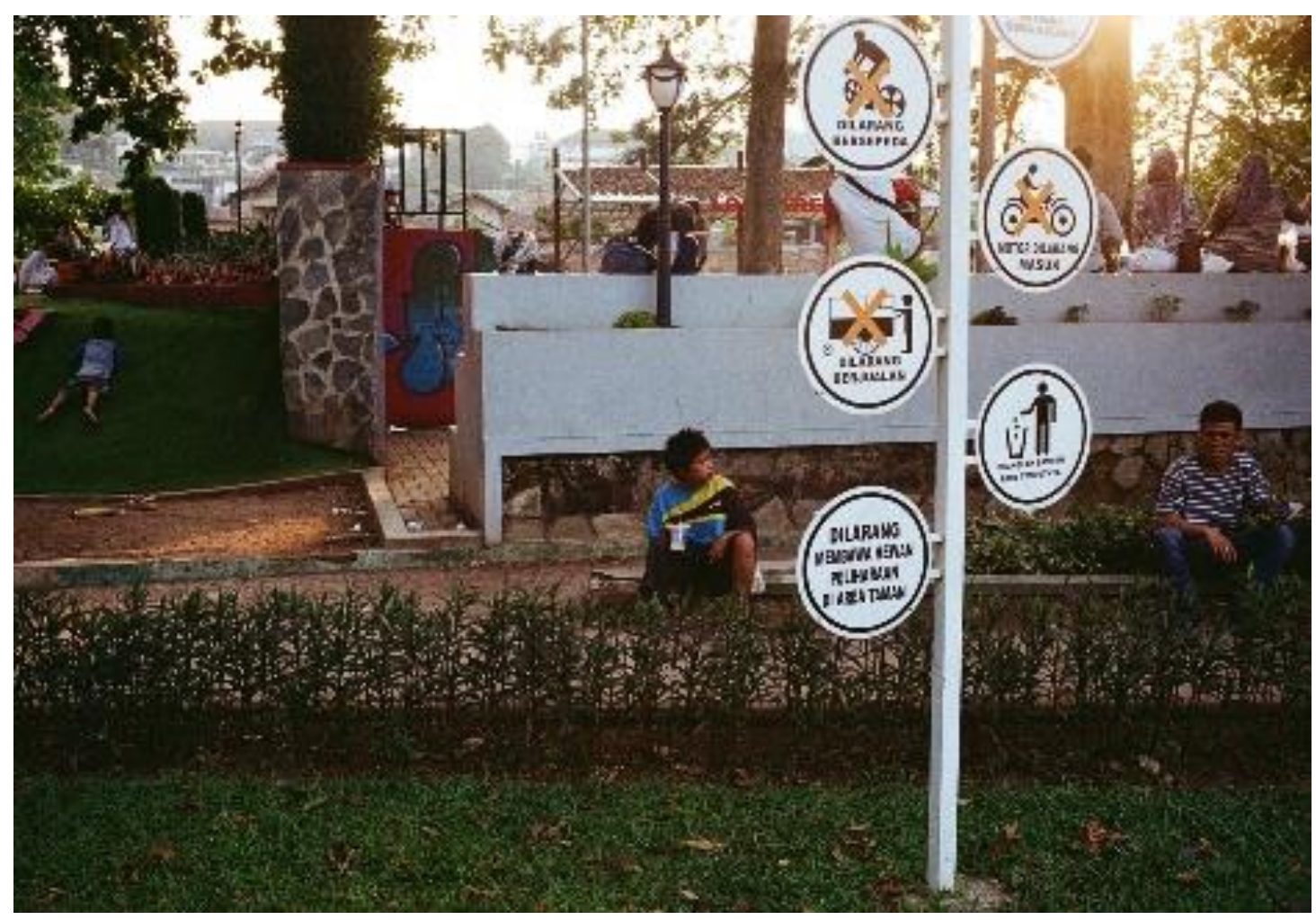

Gambar 13, Taman Sempur 


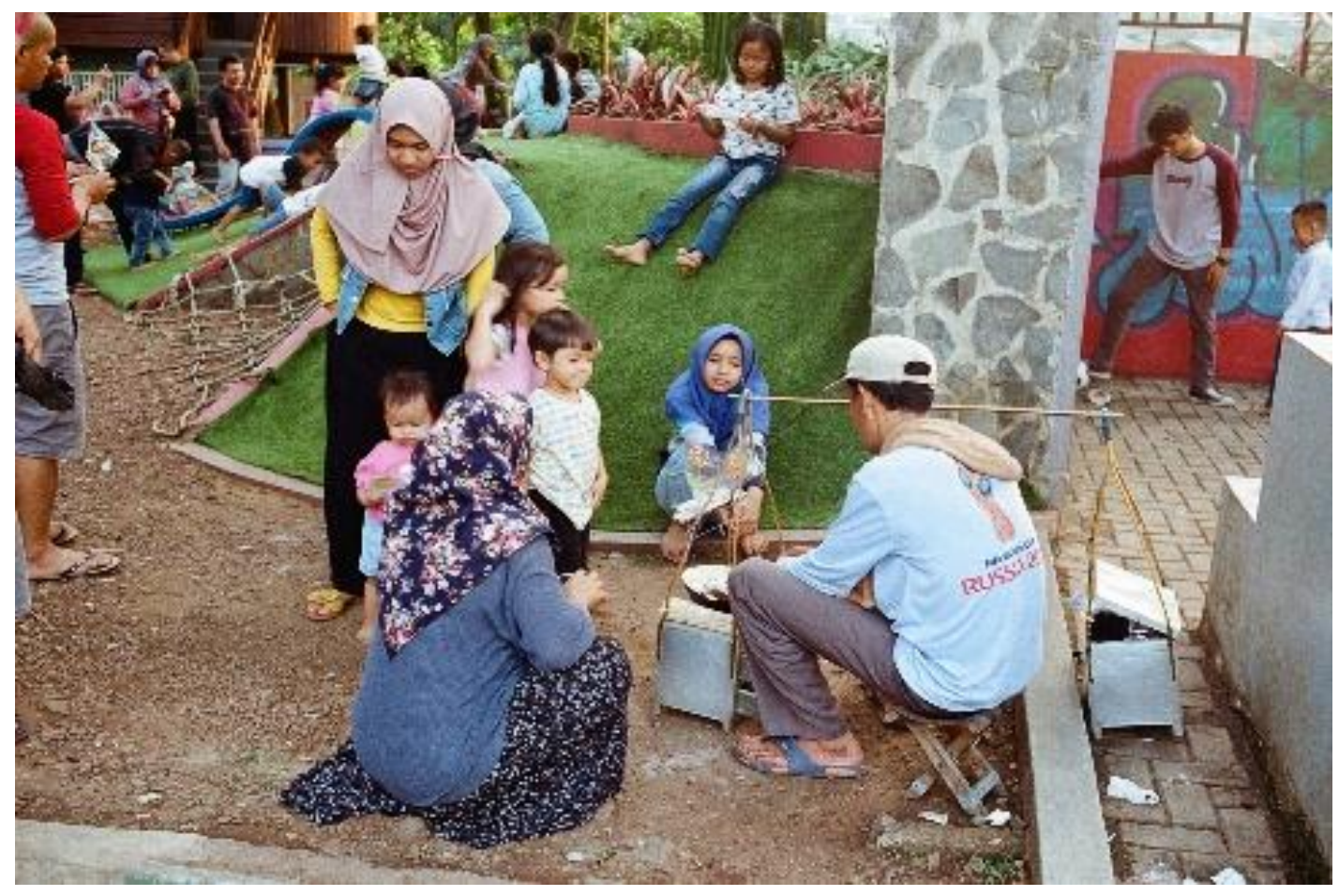

Gambar 14, Taman Sempur

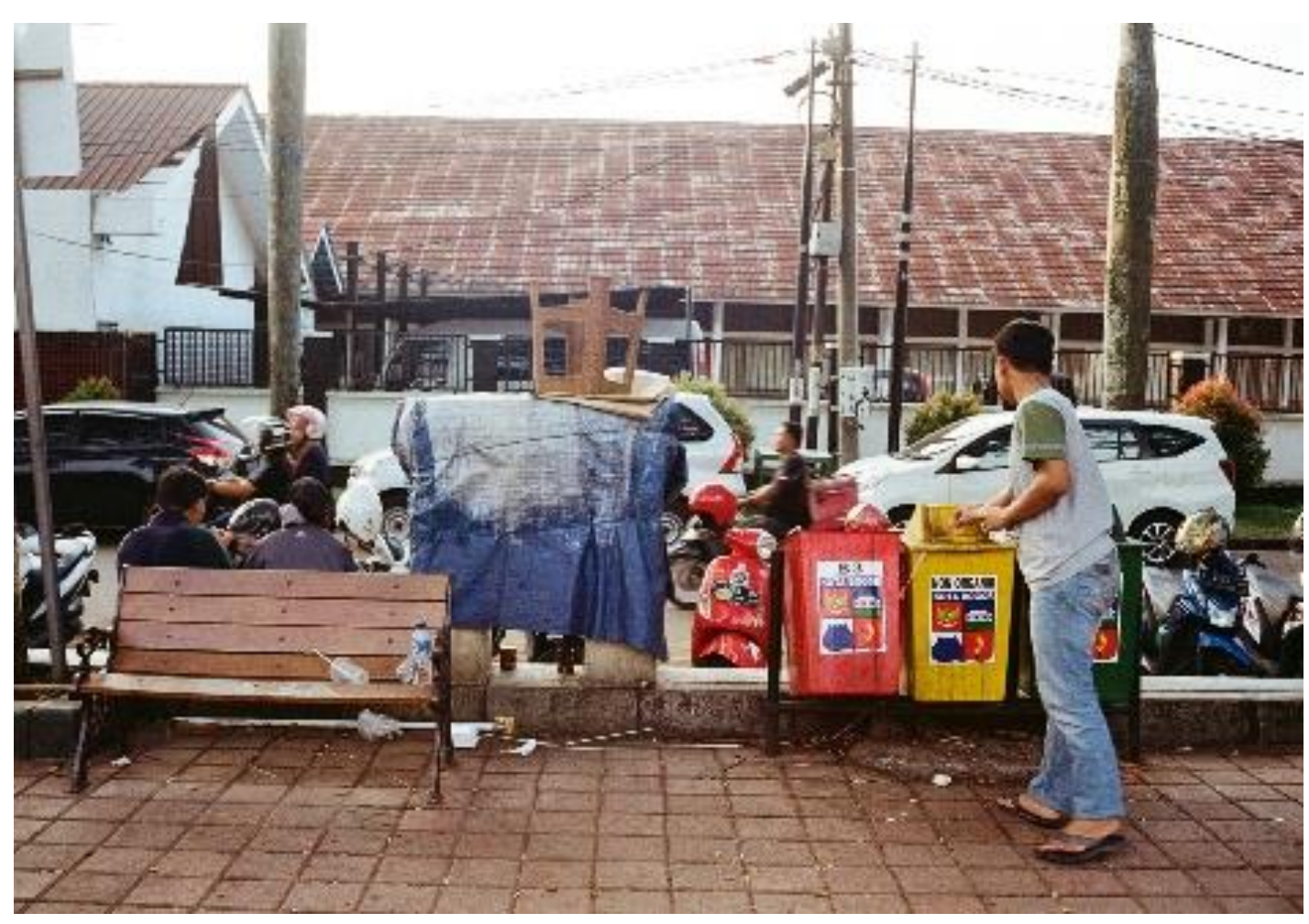

Gambar 15, Taman Sempur 
Sebagai ruang publik urban yang menyaratkan partisipasi dari seluruh warga, kita dapat melihat berbagai keterbatasan dimensi material Taman Sempur ketika berhadapan dengan habitus warga. Aturan yang eksplisit dengan berbagai ikon yang ditampilkan di pinggir lapangan utama Taman Sempur seperti: dilarang bersepeda, dilarang bermain skateboard, motor dilarang masuk, dilarang berjualan, buanglah sampah pada tempatnya dan petunjuk verbal bahwa waktu berkunjung taman pukul 07.0O-22.0o WIB dan dilarang membawa hewan peliharaan di area taman, memang ditaati. Namun, etiket publik seperti aktivitas merokok di lokasi di mana banyak anak tak jarang dilakukan oleh perokok, dan kurangnya empati terhadap para pelari di jogging track bagi mereka yang ingin masuk ke lapangan utama Taman Sempur. Kita memang jarang menjumpai sampah di lokasi lapangan utama Taman Sempur, tapi sayangnya sampah tersebut dapat dengan mudah dilihat di pedestrian yang terletak berhimpitan dengan jogging track. Kondisi tempat sampah sendiri terasa memprihatinkan karena tidak terawat. Ini yang membuat kita dapat menilik lebih jauh bagaimana habitus warga ketika berposisi sebagai bagian dari "publik" dan mengisi ruang-ruang publik. Habitus yang bisa jadi menjauhkan diri dari nalar sehat warga yang merupakan syarat terciptanya public sphere yang demokratis, dan secara niscaya menyaratkan sifat empatik.

Pada situasi keseharian, kita dapat melihat beberapa tuna wisma berada di sekitaran Taman Sempur memunguti sampah dan makanan bekas para pengunjung. Visualitas yang menjadi representasi situasi sosial bekerja di tataran yang lebih besar, dan menjadi Pekerjaan Rumah bagi Pemerintah Kota Bogor. Terdapat 71.314 Kepala Keluarga yang tercatat miskin dari jumlah total 307.730 kepala keluarga (Sarvika, Mohamad Afkar, 2017)

Begitupun dengan angka tuna wisma di Kota Bogor yang jumlahnya tercatat 700-an menurut data Badan Pusat Statistik Provinsi Jawa Barat tahun 2016 (jabar.bps.go.id). Solusi yang harus dipikirkan lebih jauh, dan tentu saja tidak dengan menggelandang mereka dan mengusir tuna wisma dari ruang publik, tapi dengan memberdayakan dan meningkatkan kualitas ekonomi mereka sehingga mereka bisa menjadi bagian dari public sphere.

\section{Kesimpulan}

Dari pembahasan yang telah dipaparkan sebelumnya, dapat ditarik kesimpulan bila Taman Sempur telah cukup mengakomodir nuansa kepublikan warga. Dalam konteks perhatian kita dalam membaca modalitas yang ada, warga bersemangat dalam berpartisipasi di Taman Sempur sebagai public space. Kekurangan yang paling besar adalah terkait fasilitas inklusif bagi penyandang disabilitas, hal yang membuat keadilan dalam hal aksesibilitas warga tidak optimal. Perawatan terhadap fasilitasfasilitas publik yang ada seperti kebersihan harus dioptimalkan oleh pengelola Taman Sempur. Dan, rekayasa terhadap lahan yang terbatas dapat terus dilakukan untuk merekayasa dimensi material yang ada di Taman Sempur sehingga dapat bermanfaat bagi seluruh warga. 
Selain itu, terdapat pekerjaan rumah yang harus dipikirkan oleh akademisi ilmu sosial dan para pemangku kebijakan, yaitu untuk dapat meningkatkan derajat dan kualitas public sphere di Taman Sempur. Hal yang terkait dengan perbaikan habitus warga, sekaligus penegakan nalar publik, mengingat keduanya adalah syarat utama bagi keberadaan public sphere.

\section{DAFTAR PUSTAKA}

Althoff, T., Sosič, R., Hicks, J. L., King, A. C., Delp, S. L., \& Leskovec, J. (2017). Large-scale physical activity data reveal worldwide activity inequality. Nature, $\quad$ 547(7663), 336-339. doi:10.1038/nature23018.

Carr, V., \& Luken, E. (2014). Playscapes: a pedagogical paradigm for play and learning. International Journal of Play, $\quad 3(1), \quad 69-83$. doi:10.1080/21594937.2013.87196

Farhan. (5 Februari 2017). Selesai Direvitalisasi, Lapangan Sempur Bogor Kembali Dibuka. Diambil dari https://news.detik.com/berita/d3414229/selesai-direvitalisasilapangan-sempur-bogor-kembalidibuka

Florida, R. (2002). The rise of the creative class: And how it's transforming work, leisure and everyday life. New York, NY: Basic Books.

Fraser, Nancy. (1990). Rethinking the Public Sphere: A Contribution to the Critique of Actually Existing Democracy. Social Text No. 25/26 (1990), pp. 56-80. 10.2307/466240

Glover, T. D. (2003). The story of the Queen Anne Memorial Garden: Resisting a dominant cultural narrative. Journal of Leisure Research, 35(2), 190-212.
Glover, T. D., \& Stewart, W. (2006). Rethinking leisure and community research: Critical reflections and future agendas. Leisure/Loisir, $30(2), 315-327$.

Habermas, J. (2008). The structural transformation of the public sphere: An inquiry into a category of bourgeois society. Cambridge: Polity.

Hartanti, Nurkhikmah Budi. (2014). Karakter Streetscape sebagai Pembentuk Identitas Kota Bogor. Seminar Nasional Riset Arsitektur dan Perencanaan (SERAP) 3 MANUSIA dan RUANG dalam ARSITEKTUR dan PERENCANAAN 22-23 Agustus 2014, Jurusan Teknik Arsitektur dan Perencanaan Universitas Gadjah Mada.

Harvey, D. (1990). The condition of postmodernity: An enquiry into the origins of cultural change, Malden, Blackwell.

Hou, J. (2010). (Not) your everyday public space. In J. Hou (Ed.), Insurgent public space: Guerilla urbanism and the remaking of contemporary cities (pp. 1-17). New York, NY: Routledge.

Hubbard, P. (2001). Sex zones: Intimacy, citizenship and public space. Sexualities, 4, 51-71. 
Jumlah Permasalahan Sosial Menurut Jenis di Jawa Barat, 2016. (16 Juli 2018).https://jabar.bps.go.id/statict able/2018/o3/19/405/jumlahpermasalahan-sosial-menurut-jenisdi-jawa-barat-2016.html

Jewitt, Carey. Bezemer, Jeff. O’Halloran, Kay (2016). Introducing Multimodality. Routledge: London dan NewYork.

L'Aoustet, O. Grirfet, J. (2004). Sharing public space: Youth Experience and Socialization in Marseille's Borely Park. Space and Culture, 7, pp 173187.

Lefebvre, H. (1991). The production of space. London, England: Basil Blackwell.

Low, S. M., \& Altman, I. (1992). Place attachment: A conceptual inquiry. In I. Altman \& S. M. Low (Eds.), Place attachment: Human behavior and environment (Vol. 12, pp. 1-12). New York, NY: Plenum Press.

Low, S.M. (2000). On the plaza: The politics of public space and culture. Austin: University of Texas Press

Lynch, K. (1984) Good City Form, Cambridge: MIT Press.

McCann, E. J. (2002). Space, citizenship, and the right to the city: A brief overview. GeoJournal, 58, 77-79

McInroy, N. (2000). Urban regeneration and public space: The story of an urban park. Space and Polity, 4, 2340 .

Norris, S. (2004). Analyzing Multimodal Interaction: A Methodological Framework. London/New York: Routledge
Nugroho, Lingga Avian. (1 Juni 2018). Selama Tiga Tahun ke Belakang, Sudah Ada 30 Taman Di Kota Bogor yang Direvitalisasi. Diambil dari http://bogor.tribunnews.com/2018/ o6/o1/selama-tiga-tahun-kebelakang-sudah-ada-30-taman-dikota-bogor-yang-direvitalisasi

Pask, A. (2010). Public space activism, Toronto and Vancouver: Using the banner of public space to build capacity and activate change. In J. Hou (Ed.), Insurgent public space: Guerrilla urbanism and the remaking of contemporary cities (pp. 227240). New York, NY: Routledge.

Picione, Raffaele De Luca. Martino, Maria Luisa. Freda, Maria Fransesca. (2017). Modal articulation: The psychological and semiotic functions of modalities in the sensemaking process.

Rahmawati Laily. (15 November 2015). Pemkot Bogor Bangun Taman Ekspresi. Diambil dari https://megapolitan.antaranews.co $\mathrm{m} /$ berita/16933/pemkot-bogorbangun-taman-ekspresi

Rotenberg, R. (2005). Landscape and power in Vienna: Gardens of discovert in S. Low, ed Theorizing the city: The new urban Anthropology reader. New Brunswick: Rutgers University Press.

Sarvika, Mohamad Afkar. (1 Oktober 2017). 71 Ribu Keluarga di Kota Bogor Hidup Miskin, Begini Cara Pemkot Mengatasinya. Diambil dari http://bogor.tribunnews.com/2017/ 10/o1/71-ribu-keluarga-di-kotabogor-hidup-miskin-begini-carapemkot-mengatasinya 
Schaller, S., \& Modan, G. (2005). Contesting public space and citizenship: Implications for neighborhood business improvement districts. Journal of Planning Education and Research, 24, 394-407.

Scollon, R., \& Scollon, S. B. K. (2003). Discourses in place: Language in the material world. London: Routledge.

Shinew, K. J., Glover, T. D., \& Parry, D. C. (2004). Leisure spaces as potential sites for interracial interaction: Community gardens in urban areas. Journal of Leisure Research, 36(3), $336-355$.

Stutzin, Nicolas. (2015). Politics of the Playground: The Spaces of Play of Robert Moses y Aldo van Eyck. ARQ (Santiago) no.91 Santiago Dec. 2015. http://dx.doi.org/10.4067/So71769962015000300005 .

Theory \& Psychology Vol 28, Issue 1, 2018. https://doi.org/10.1177/0959354317 743580
Tan, Qian Hui (2012). Smell in the City: Smoking and Olfactory Politics. Urban Studies Vol 50, Issue 1, 2013. https://doi.org/10.1177/004209801 2453855

Utama, I Gusti Bagus Rai. (2013). Pengembangan Wisata Kota Sebagai Pariwisata Masa Depan Indonesia. Prosiding Seminar Nasional Space \# I - Agustus 2013. Denpasar: Universitas Hindu Indonesia (UNHI).

Warpole, K. (1997). The richness of cities: Urban policy in a new landscape. London, England: Comedia and Demos.

Weszkalnys, G. (2010). Berlin, Alexanderplats: Transforming place in a unified Germany, Berghann Books. 